\author{
PATRICIA CAROT Y MARIE-ARETI HERS \\ CENTRO DE ESTUdIOS MEXICANOS Y CENTROAMERICANOS/ \\ UNIVERSIDAD NACIONAL AUTÓNOMA DE MÉXICO \\ INSTITUTO DE INVESTIGACIONES ESTÉTICAS \\ MÉXICO
}

\title{
De perros pelones, buzos y Spondylus \\ Una historia continental
}

$\mathrm{L}$ as relaciones entre Mesoamérica y el mundo andino constituyen, sin duda, una larga y compleja historia que ya ha sido abordada por numerosos investigadores. ${ }^{\mathrm{I}}$ Los intercambios parecen remontarse por lo menos a los tiempos de la dispersión y domesticación de cultígenos tan importantes como el maíz, la yuca o el cacao. En este campo, las hipótesis siguen modificándose a la luz de nuevos descubrimientos y se multiplican las evidencias de que muchos de los elementos tomados en cuenta cuando se analizan las relaciones entre Mesoamérica y el mundo andino resultan ser más antiguos en el sur. ${ }^{2}$ Para abordar la complejidad de la evolución de dichas relaciones, las

I. Véase, por ejemplo, el Primer Simposio de Correlaciones Antropológicas Andino-mesoamericano, 25-3I de julio, I97I, Salinas-Ecuador, eds. Jorge G. Marcos y Presley Norton (Guayaquil: Escuela Superior Politécnica del Litoral, 1982) o la reseña presentada por Patricia Rieff Anawalt, "They Came to Trade Exquisite Things: Ancient West Mexican-Ecuatorian Contacts", en Ancient West Mexico. Art and Archaeology of the Unknown Past, ed. Richard Towsend (The Art Institute of Chicago, 1998), 233-250.

2. Así, trabajos recientes en la selva amazónica ecuatoriana han revelado el uso sorprendentemente temprano del cacao, en el tercer milenio antes de la era actual, asociado de manera directa a los famosos botellones de asa de estribo: Francisco Valdez, "El surgimiento de un centro de poder temprano en la Alta Amazonía”, ponencia presentada en el Segundo Coloquio Internacional Arte, Arquitectura, Cosmovisión y Patrimonio Cultural en el Mundo Mesoamericano y 
insuficiencias de las cronologías disponibles y la destrucción de los contextos arqueológicos ocasionada por el saqueo y el coleccionismo siguen siendo uno de los principales problemas. ${ }^{3}$ Sin embargo, se ha logrado un amplio consenso para reconocer que desde tiempos remotos, y hasta la conquista española, pueblos del Occidente de México y de la costa ecuatoriana tuvieron un papel destacado en esta interacción entre continentes por medio de complejas redes de navegación marítima.

En los límites del presente trabajo, nos centraremos en la posible participación de los tarascos o purépechas en este ámbito, en tiempos previos al pleno desarrollo de la metalurgia en Mesoamérica, en la cual los tarascos alcanzaron un notable dominio tecnológico gracias a sus contactos con Centro y Sudamérica. ${ }^{4}$ Para tal efecto, vincularemos una serie de datos, a primera vista inconexos, acerca de navegantes, de buzos y mercaderes, de perros pelones y de la muy preciada concha del Spondylus. Sin embargo, antes de mirar hacia el sur, es necesario hacer una digresión sobre asuntos relacionados con un norte muy lejano, para esclarecer ciertos aspectos importantes de la historia purépecha o tarasca.

Andino; estos descubrimientos cuestionan lo que se sabía del uso antiguo de dicha bebida. Véase, por ejemplo, Cameron L. McNeil, "Introduction. The Biology, Antiquity, and Modern Uses of the Chocolate Tree (Theobroma cacao L.)”, en Chocolate in Mesoamerica. A Cultural History of Cacao (Gainesville: University of Florida, 2006), I-28. Sobre la importancia del Formativo ecuatoriano, colombiano y de la cuenca amazónica en la evolución de la agricultura y de la cerámica temprana, véase Donald W. Lathrap, El Ecuador antiguo. Cultura, cerámica y creatividadlAncient Ecuador. Culture, Clay and Creativity (Guayaquil y Chicago: Museo del Banco del Pacífico/Field Museum of Natural History, 1998); respecto a las relaciones de la cultura Tlatilco con el mundo andino vía el Occidente de México, véase David C. Grove, "The Mesoamerican Formative and South America”, en Primer Simposio de Correlaciones Antropológicas, 279-300; Isabel Kelly, Ceramic Sequence in Colima: Capacha, An Early Phase, Anthropological Papers of the University of Arizona, 37 (Tucson: The University of Arizona Press, 1980), 37-38.

3. Tal es el caso, por ejemplo, cuando se trata de comparar el origen y la evolución de las tumbas de tiro: Clifford Evans y Betty J. Meggers, "Mesoamerica and Ecuador", Handbook of Middle American Indians, vol. 4 (Austin: University of Texas Press, 1966), 260. Estos autores retoman la idea ampliamente difundida de que las tumbas de tiro son de origen sudamericano, por su amplia distribución y larga duración desde la mitad del primer milenio hasta la Conquista. Sin embargo, tal idea contradice en cierta medida las fechas más antiguas establecidas para el Occidente de México: Kelly, Ceramic Sequence in Colima, 36.

4. Frente a la complejidad lingüística y étnica del Occidente, denominamos de modo genérico como purépechas o tarascas a las comunidades asentadas originalmente en tierras michoacanas, sin poder precisar el o los idiomas y las entidades étnicas implicados ni los límites territoriales. 


\section{Un asunto de vestimenta}

Nuestro punto de partida es un trabajo muy interesante de Patricia Rieff Anawalt, especialista en la vestimenta mesoamericana. Con base en las imágenes de la temprana Relación de Michoacán, ella advierte que la ropa de los hombres y las mujeres tarascos es totalmente distinta a la de todos los otros grupos mesoamericanos: para los hombres consistía en unos pantalones cortos en lugar del taparrabo y, en lugar de la capa anudada al hombro, una camisa sin manga de la cual los mexicas se burlaban porque se parecía al huipil de las mujeres. A menudo la ropa presenta diseño de cuadros nada comunes en Mesoamérica, pero sí en el mundo andino. Las mujeres, en lugar del huipil, portaban una falda muy corta con rayas o cuadros, llevaban el torso desnudo o con un diminuto quechquemitl.

Al buscar el posible origen de este singular vestuario, esta autora encuentra fuertes similitudes con el que se usó en la costa ecuatoriana, tal como lo documentan tanto materiales arqueológicos como testimonios históricos. Así, en la provincia costera de Manabí, en particular en el sitio de Chacras, durante la fase Chorrera (I500-300 a.C.), las esculturas en terracota de mujeres llevan faldas cortas y mantos miniatura y los hombres pantalones y camisas cortos. Muchos siglos después, los acompañantes de Pizarro visitaron las aldeas de los comerciantes ecuatorianos y describieron faldas para las mujeres y para los hombres, pantalones cortos de diversos colores y camisas de lana bordadas.

Al remontarse al tiempo de los tarascos, Anawalt encuentra como antecedente en el Occidente las famosas esculturas polícromas con vestimenta similar que pertenecen al estilo Ixtlán de Nayarit de la cultura de las tumbas de tiro.

\section{El callejón sin salida del tarasco visto como chichimeca}

Al llegar a este momento, la investigadora se enfrenta con un enigma, un callejón aparentemente sin salida. Los tarascos estaban orgullosos de su pasado "chichimeca", por lo que ella prosigue su búsqueda e indaga en la vestimenta de tales "chichimecas". Hay que recordar que se suele entender por "chichimeca" a diversos pueblos nómadas que poblaban el norte de México a la llegada de los españoles y contra los cuales llevaron a cabo una cruenta guerra durante

5. Anawalt, "They Came to Trade Exquisite Things". 
medio siglo en la que, por cierto, los tarascos, junto con otros grupos mesoamericanos, lucharon como aliados de los españoles. Al buscar información sobre la ropa que llevaban esos diversos grupos nómadas del norte de México en el siglo XVI, y luego, más al norte aún, los grupos agricultores llamados genéricamente pueblos en el suroeste de los Estados Unidos hoy, Anawalt no encuentra nada similar y se queda perpleja, suponiendo que estas singulares ropas habrían sido herencia de algunos de los varios grupos locales del Occidente con los cuales los tarascos se unieron para formar su imperio. Pero, ¿eran los tarascos realmente nómadas originarios del norte?

\section{Una larga historia recuperada}

Es sobre este tema donde intervienen los trabajos llevados a cabo en el marco de un amplio proyecto arqueológico francés en el estado de Michoacán, en particular en la región de la antigua ciénega de Zacapu. ${ }^{6}$ En primer lugar, en contradicción plena con la versión tradicional de la historia que consideraba la llegada de los tarascos como una profunda ruptura, como la intrusión de un pueblo nómada norteńo, se demuestra una notable continuidad en la ocupación desde siglos antes de la era y hasta la llegada de los españoles. Se hace evidente así que la historia tarasca no empieza apenas unos cuantos siglos antes de la Conquista como se solía considerar, sino mucho tiempo atrás. En particular se detecta una fase fundamental en esta larga historia recobrada, la fase Loma Alta (Ioo a.C.- 600 d.C.), que puede considerarse como una continuidad de la cultura Chupícuaro (60o-Ioo a.C.), tan relevante en la historia antigua del Occidente y del centro del país. Para la fase Loma Alta misma, se

6. Marie-Charlotte Arnauld, Patricia Carot y Marie-France Fauvet-Berthelot, Arqueología de las Lomas en la cuenca lacustre de Zacapu, Cuadernos de Estudios Michoacanos 5 (México: Centro de Estudios Mexicanos y Centroamericanos, 1993); Patricia Carot, Le site de Loma Alta, lac de Zacapu, Michoacan, Mexique, International Series 920 (Óxford: BAR, 200I); "Reacomodos demográficos del Clásico al Posclásico en Michoacán: el retorno de los que se fueron", en Reacomodos demográficos del Clásico al Posclásico en el centro de México, ed. Linda Manzanilla (México: Universidad Nacional Autónoma de México-Instituto de Investigaciones Antropológicas, 2005), I03-I2I; "Otra visión de la historia purépecha", en Estudios Jaliscienses, núm. 7I (2008): 26-40; "La larga historia purépecha", en Miradas renovadas al Occidente indigena de México, ed. Marie-Areti Hers (México: Universidad Nacional Autónoma de México-Instituto de Investigaciones Estéticas/Instituto Nacional de Antropología e Historia/ Centro de Estudios Mexicanos y Centroamericanos, 2013), I33-2I4. 
documentan fuertes lazos con la gran metrópoli teotihuacana desde sus orígenes y hasta su trágico final y la diáspora de su población alrededor de 600 d.C. Probablemente, en relación directa con los acontecimientos que marcaron el fin de este gran centro de saber, ocurrió en tierras michoacanas un fenómeno similar: una grave crisis religiosa y política que se tradujo en ceremonias de clausura de espacios sagrados, en un rechazo posterior de las imágenes antiguas y en el exilio de un grupo hacia el norte.

\section{El mundo de los purépechas o tarascos se ensancha hacia el norte}

Se pueden seguir las huellas de los tarascos gracias al hecho de que, en contraste con sus congéneres que se quedaron en tierras michoacanas, estos emigrantes se llevaron consigo sus imágenes, su arte figurativo muy singular y sus ritos funerarios, los cuales dejaron su impronta en los pueblos mesoamericanos de la Sierra Madre Occidental de la cultura Chalchihuites entre quienes se instalaron, y en las comunidades hohokam del desierto de Arizona con las que entablaron estrechas relaciones. ${ }^{8}$

La llegada de estos grupos purépechas a tierras chalchihuiteñas favoreció una considerable expansión territorial cientos de kilómetros más al norte en el actual estado de Durango. Esos movimientos migratorios no fueron totalmente azarosos. Algo se buscaba al norte, algo que se ignora aún. Lo que se sabe es que quienes encabezaron la colonización mesoamericana de estas nuevas tierras fueron sabios astrónomos formados en la antigua metrópoli, como lo atestigua una ruta de los llamados marcadores astronómicos de clara tradición teotihuacana, diversas expresiones de arte rupestre y ciertas características de la orientación de las construcciones. ${ }^{9}$ Estos estrechos lazos que unieron sobre

7. Patricia Carot, "Cuando se abandonaron las imágenes sagradas: un ritual de clausura purépecha del siglo vi en Loma Alta, Zacapu, Michoacán”, en Imagen, símbolos y metáforas del poder en Mesoamérica, ed. Guilhem Olivier (México: Universidad Nacional Autónoma de México-Instituto de Investigaciones Históricas, 2008), 23I-26I.

8. Patricia Carot y Marie-Areti Hers, "La gesta de los tolteca chichimecas y de los purépechas en las tierras de los pueblo ancestrales", en Las vias del noroeste I: una macrorregión indígena americana, eds. Carlo Bonfiglioli, Arturo Gutiérrez y María Eugenia Olavaria (México: Universidad Nacional Autónoma de México-Instituto de Investigaciones Antropológicas, 2006), 47-82.

9. Daniel Flores, Marie-Areti Hers y Antonio Porcayo, "Sobre el trópico en un mar de lava: análisis astronómico, arqueológico e iconográfico en el septentrión mesoamericano”, en 
distancias considerables el mundo de los antepasados de los indios pueblo y el mesoamericano dejaron una huella duradera en la cosmología y los rituales de muchos pueblos actuales. Para sabios hopis de Arizona con quienes hemos tenido la oportunidad de interactuar, estas evidencias arqueológicas confirman su propia tradición oral relativa al origen sureño de varios de los clanes que conformaron sus pueblos actuales. ${ }^{\text {IO }}$

Estos mesoamericanos son norteños que muy tempranamente, por contacto con sus tierras de origen en el Occidente de México, adquirieron las sonajas de cobre y las llevaron al lejano Southwest tanto en tierras hohokam como hasta el gran centro religioso de Cañón de Chaco en Nuevo México. El ancho mundo norteño en el cual se movieron estos antiguos tarascos junto con otros grupos mesoamericanos y pueblo encuentra en el mecapalero su imagen más elocuente. Éste junto con el flautista son los emblemas por excelencia de esas migraciones de las cuales conservan la memoria los sabios hopis. Hay que recordar que los mecapaleros tarascos seguían recorriendo ese anchísimo mundo a principios del siglo xx como lo ha documentado el viajero Carl Lumholtz. ${ }^{\text {II }}$

En vista de lo anterior, es sorprendente, pero no inexplicable, encontrar en la cuenca de los ríos Balsas y Tepalcatepec —en los límites entre los estados actuales de Michoacán y Guerrero, en el extremo sur del vasto paisaje tarasco de esta época- - un tipo de objeto característico de la muy lejana cultura hohokam del desierto de Arizona y ajeno a la cultura material mesoamericana: la paleta de piedra, pequeña piedra plana destinada probablemente a moler pigmentos. Es un componente común en los ajuares funerarios de las

Las vías del noroeste II: propuestas para una perspectiva sistémica e interdisciplinaria, eds. Carlo Bonfiglioli, Arturo Gutiérrez, Marie-Areti Hers y María Eugenia Olavaria (México: Universidad Nacional Autónoma de México-Instituto de Investigaciones Antropológicas, 2008), 24I-286; Patricia Carot y Marie-Areti Hers, "La Mesoamérica septentrional y el saber astronómico teotihuacano”, en El legado astronómico, coords. Daniel Flores Gutiérrez, Margarita Rosado Solís y José Franco López (México: Universidad Nacional Autónoma de MéxicoInstituto de Astronomía, 20II), I83-196.

Io. Patricia Carot y Marie-Areti Hers, "De Teotihuacan al cañón de Chaco: nueva perspectiva sobre las relaciones entre Mesoamérica y el suroeste de los Estados Unidos", Anales del Instituto de Investigaciones Estéticas XXXIII, núm. 98 (2011): 5-54; Kelley Hays-Gilpin, "All Roads Lead to Hopi", en Las vias del noroeste II, $65-82$.

II. Carl Lumholtz, Unknown México; a Record of Five Years' Explorations among the Tribes of the Western Sierra Madre; in the Tierra Caliente of Tepic and Jalisco; and among the Tarascos of Michoacan, 2 tomos, introd. Thomas B. Hinton (Glorieta, Nuevo México: The Rio Grande Press, 1973 [reimpresión de la edición de I902]): t. I, 4I9 y t. II, 358. 
incineraciones hohokam y, entre 700 y 900 de la era, suelen estar ornamentadas con la figura de un animal. ${ }^{22}$ Hasta ahora en la región del Balsas se han encontrado medio centenar de estos utensilios asociados generalmente a objetos de concha. ${ }^{13}$ ¿Habrán llegado por el camino de tierra adentro, forjado por los migrantes tarascos en su avanzada al norte y que acabamos de evocar, o por vía marítima? Aún no lo sabemos.

Lo cierto es que cuando a partir del siglo Ix, los muy diversos grupos mesoamericanos que habían colonizado el ancho septentrión, empezaron a abandonar estos confines y regresaron a las tierras de sus antepasados, figuraban entre ellos los tarascos quienes, por tanto, no eran "chichimecas" por ser nómadas sino "chichimecas" por tener un origen norteńo: confusión alrededor de un apelativo, alimentada por el desconocimiento y los prejuicios que persisten hasta el día de hoy sobre la historia del septentrión mesoamericano.

\section{Los tarascos en medio del enigmático encuentro de dos mundos}

A principios del siglo $\mathrm{xx}$, un explorador hizo el descubrimiento cerca del poblado de Placeres del Oro, en la cuenca del Balsas y próximo a Zirándaro, de un sepulcro sorprendente, al pie de una pirámide y cerca de lo que parece ser una cancha de juego de pelota. Su registro pormenorizado lo publicó Herbert J. Spinden y hallazgos posteriores reforzaron los indicios que ofrecía este primer conjunto. ${ }^{14}$

Se trata de una fosa rectangular cuyas paredes de tierra se endurecieron por el calor de los restos de un ritual de incineración que se depositaron aún calientes en la tumba. Al fondo se depositó una losa esculpida con la cara

I2. Emil W. Haury, The Hohokam: Desert Farmers and Craftsmen; Excavations at Snaketown 1964-1965 (Tucson: The University of Arizona Press, 1976), 286-289.

I3. Rubén Maldonado Cárdenas, "Las paletas del Infiernillo, Michoacán-Guerrero y los hohokam del suroeste de los Estados Unidos”, en El pasado arqueológico de Guerrero, coords. Christine Niederberger y Rosa María Reyna Robles (México: Centro de Estudios Mexicanos y Centroamericanos/Gobierno del Estado de Guerrero/Instituto Nacional de Antropología e Historia, 2002), I5I-I74; Rosa María Reyna Robles, "Esculturas, estelas y lápidas de la región del Balsas: acercamiento a su cronología e interpretación”, en El pasado arqueológico de Guerrero, 370, fig. 3 .

I4. Herbert J. Spinden, "An Ancient Sepulcher at Placeres del Oro, State of Guerrero, Mexico", American Anthropologist, núm. I3 (I9II): 29-55; Reyna Robles, "Esculturas, estelas y lápidas de la región del Balsas", 36I-364, figs. I-5. 
decorada hacia abajo, encima descansaron las cenizas y fragmentos de huesos humanos no totalmente consumidos por el fuego, junto con diminutas urnas de piedra y abundantes ornamentos de concha. El conjunto se tapó con otra lápida esculpida con la cara hacia abajo por lo que sufrió la acción del fuego. Finalmente se cerró la fosa con otras dos losas mayores sin decorar. Lo enigmático es que entre el ajuar funerario figuraba una de estas paletas hohokam de piedra, pero decorada con un motivo cercano a la ornamentación de las dos lápidas, y éstas son estilística e iconográficamente ajenas al mundo mesoamericano. Nos obligan a mirar hacia el sur, hacia un muy lejano sur andino. Años después, el artista y estudioso Miguel Covarrubias encontró una lápida emparentada con las de Placeres del Oro y le vio una apariencia cercana a los relieves de Chavín. Recientemente se encontró otra lápida más, procedente de la misma región, la cual está actualmente en el museo de Arcelia, Guerrero. ${ }^{\text {I5 }}$

Como se puede apreciar (fig. Ia) en la primera lápida de Placeres del Oro predomina una cara humana con el corte de pelo escalonado; una línea ondulada se extiende sobre la frente a manera de cejas juntas. Los ojos circulares, marcados por profundas oquedades, probablemente rellenadas en su forma original por alguna sustancia, están rodeados por líneas ondulantes de serpientes que empiezan en la nariz y después de contornear los ojos, se doblan con la cabeza dirigida hacia afuera. La boca enseña dientes aserrados y dos largos colmillos en la quijada superior, con lo que parecen ser bigotes y una barba a su alrededor.

La cara de este ser poderoso emerge de una U angulosa, formada por la conjunción de las cabezas de dos animales con el hocico enroscado hacia arriba y las fauces abiertas, delineadas por un trazo aserrado de dientes. Los ojos, en forma de diamante, se cruzan por una L. En el registro inferior de la lápida se encuentran las mismas dos cabezas, esta vez opuestas, mirando hacia afuera y en la boca de cada una, una forma de $\mathrm{S}$ o xonecuilli.

El contorno de la segunda lápida, que descansaba encima de los restos funerarios, sigue el de la figura grabada compuesta de tres partes: una cara inscrita en un rectángulo, un recipiente en $U$ que la sostiene y lo que parece la entrada de un edificio (fig. Ib). Se reconoce el mismo corte de pelo escalonado, una línea ondulada que cruza la frente; dos líneas enmarcan las fosas nasales, recorren los lados de la nariz, prosiguen encima de los ojos, y a la altura de los tímpa-

I5. Reyna Robles, "Esculturas, estelas y lápidas de la región del Balsas", ilustra las cuatro lápidas conocidas hasta ahora. 

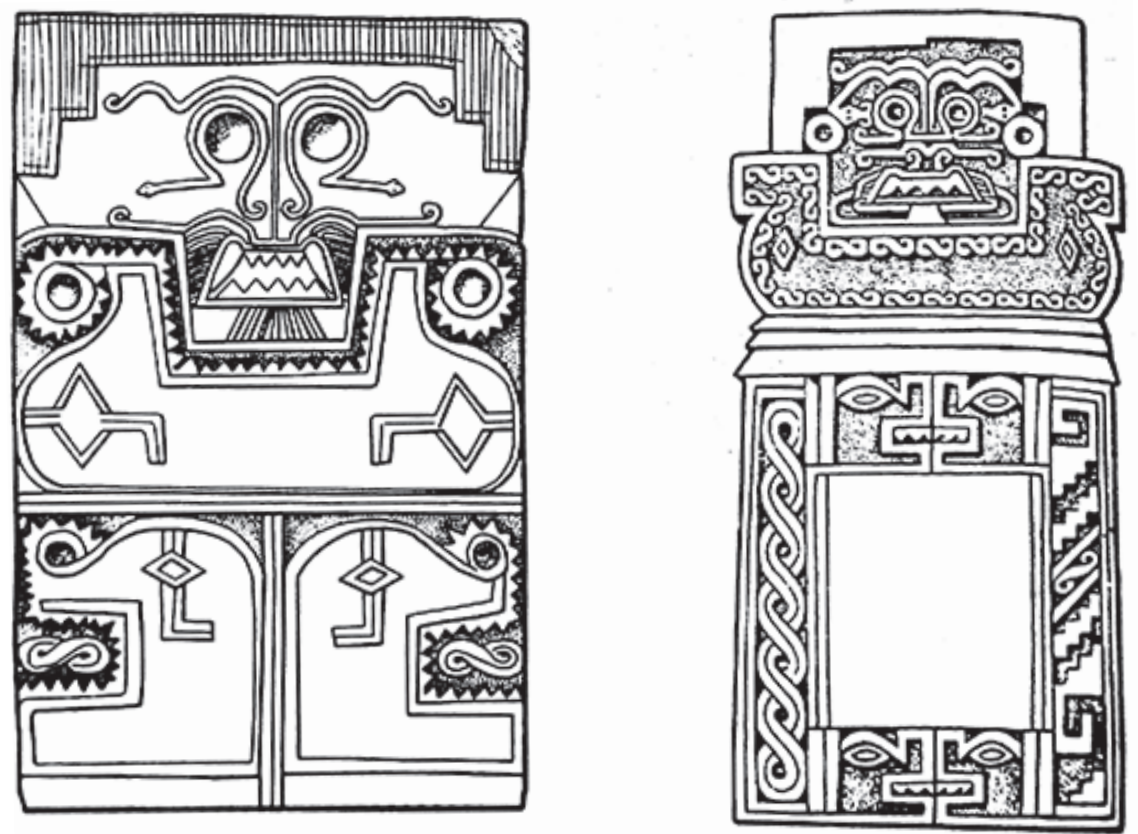

I. Las dos lápidas de Placeres del Oro, dibujos retomados de Reyna Robles, "Esculturas, estelas y lápidas de la región del Balsas" (vid supra n. I3), fig. 2.

nos acaban en la cabeza de dos serpientes volteadas hacia los ojos. Éstos están enmarcados por una línea que empieza con un gancho debajo de las cabezas de las serpientes, rodean los ojos y se juntan en una línea horizontal debajo de la nariz. Las fosas nasales se ven de frente debajo de otra franja horizontal que las delinea y termina de cada lado por un gancho. La boca presenta tres dientes aserrados y dos colmillos, sin mandíbula inferior, pero quizá con una lengua de forma trapezoidal extendida hacia abajo. En ambos lados, líneas horizontales marcan quizá los bigotes. La boca parece salir de un gran óvalo que la rodea. Este ser emerge de un recipiente en forma de U, quizá de las aguas del inframundo, formado por dos cabezas divergentes, con hocico enroscado hacia arriba y ojos en forma de diamantes. En lugar de la línea aserrada a manera de dientes, el contorno de ambas cabezas está marcado por una línea lisa y, adentro, una línea continua de xonecuilli. 


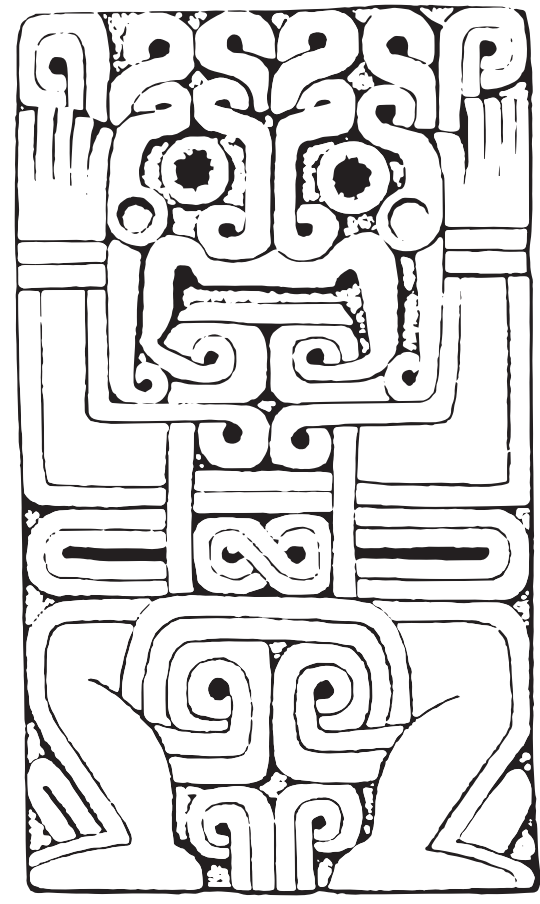

2. Lápida de probable procedencia de Placeres del Oro, publicada por Miguel Covarrubias. Dibujo retomado de Robles, "Esculturas, estelas y lápidas de la región del Balsas" (vid supra $\mathrm{n} .13)$, fig. $4^{\mathrm{a}}$.

La parte inferior de la lápida, de forma rectangular alargada, tiene al centro un rectángulo sin decorar, bordeado por dos serpientes de perfil, de doble cabeza y hocico enroscado hacia arriba, dispuestas simétricamente, que se encuentran arriba y abajo; al juntarse, las cabezas forman una cara vista de frente con la mandíbula superior provista de dientes aserrados. El cuerpo de la serpiente de la izquierda está decorado con una banda de triple línea enroscada sobre sí misma; el de la derecha con dos grecas escalonadas divergentes y, entre ellas, una banda oblicua que encierra un xonecuilli. Por su forma trapezoidal subdividida en tres bandas horizontales, la unión entre las dos partes de la lápida evoca la pendiente de un techo de palma. Si esta interpretación fuera cierta, el rectángulo inferior sería la puerta de un recinto resguardado por las dos serpientes, y la cara que emerge de la $\mathrm{U}$, su coronamiento o la figura sagrada resguardada en el interior del recinto.

En la lápida publicada por Miguel Covarrubias, reconocemos al mismo ser poderoso (fig. 2). Ahora no parece emerger de un recipiente, pues se le ve de 
3. Lápida, Museo de Arcelia, Guerrero. Dibujo retomado de Reyna

Robles, "Esculturas, estelas y lápidas de la región del Balsas (vid supra n. I3),

fig. 5 .

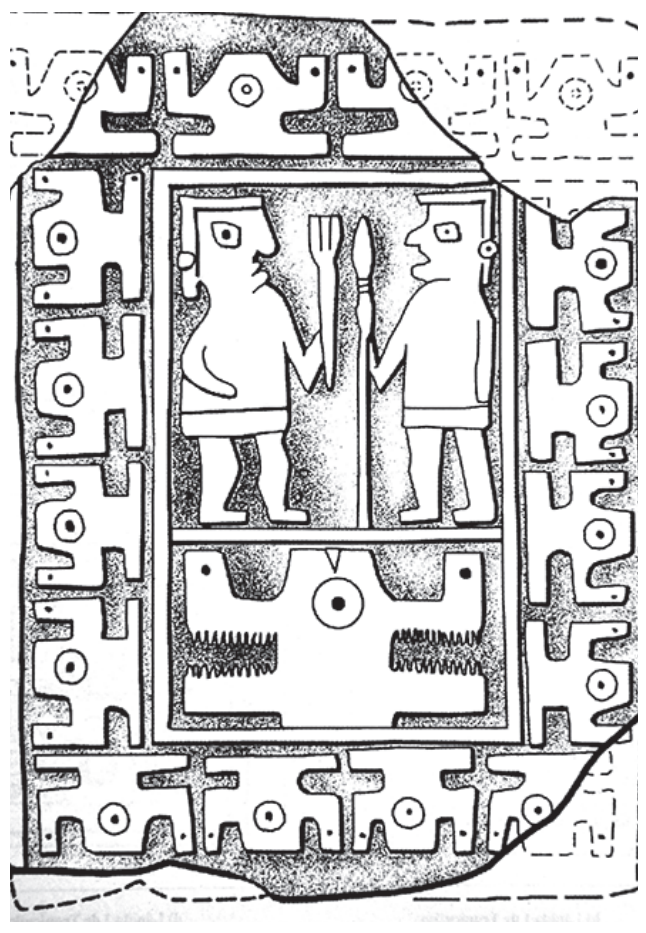

frente de cuerpo entero, brazos y piernas flexionados. Tiene los mismos ojos redondos y profundos para ser engastados en algún material; la boca abierta con los colmillos amenazantes. Con algunas variantes, la cara presenta también líneas ondulantes trenzadas que evocan serpientes.

La cuarta lápida tiene forma y dimensiones similares a las de Placeres del Oro (de 70 a $80 \mathrm{~cm} \times 40$ a $50 \mathrm{~cm}$ y $5 \mathrm{~cm}$ de grosor) y, a pesar de la esquematización pronunciada, se aprecia en el friso que bordea la pieza las cabezas opuestas de serpientes con el hocico en roscado (fig. 3). Al centro se ven dos personajes de pie uno frente al otro portando una suerte de saco. Uno empuña un tridente, el otro una lanza. Rosa María Reyna Robles, quien publica esta pieza y la relaciona también con las anteriores, propone reconocer, a la izquierda, a un anciano denotado por la nariz aguileña, el mentón curvado hacia arriba como si el personaje estuviera sin dientes y el cuerpo más macizo. Estas figuras se levantan sobre una línea de suelo encima de dos cabezas de animales similares a las de las lápidas de Placeres del Oro, con hocico enros- 
cado hacia arriba y dientes aserrados; miran en direcciones opuestas, pero comparten un solo ojo.

Si seguimos la propuesta de Miguel Covarrubias, se identifica en el Lanzón de Chavín al mismo ser poderoso con los ojos redondos rodeados de serpientes, las fosas nasales vistas de frente, la boca aserrada abierta con los colmillos amenazantes $y$, alrededor, el mismo motivo de las dos cabezas encontradas de serpientes con la boca aserrada y el hocico enroscado hacia arriba (fig. 4). Pero las fechas no concuerdan y esta propuesta de Covarrubias ha sido refutada por estudiosos del arte de Chavín, aunque no su origen andino. ${ }^{16}$ En estas circunstancias, solamente trabajos futuros por parte de especialistas del arte andino permitirían profundizar en la identificación estilística y en el sentido simbólico de dichas obras.

Queda por ahora la pregunta centrada en la presencia misma, hacia el siglo viII o IX de la era, de estas obras relativamente fáciles de transportar, y tan lejos de su lugar de origen. Es pertinente retomar al respecto el parecer de Rosa María Reyna Robles, estudiosa de la arqueología guerrerense, que relaciona la presencia de esas lápidas con otros indicios de intercambios con Centro y Sudamérica. Menciona la llamada cerámica Yestla Naranjo, similar a una producción alfarera de Costa Rica, y reporta, en el sitio de La Organero-Xochipala que excavó, la presencia de un granero emplazado en un antiguo palacio abandonado y que contenía una cantidad considerable de mazorcas carbonizadas, entre las cuales se reconocieron razas centro y sudamericanas. ${ }^{17}$

También es enigmático el origen de la o las personas incineradas en Placeres del Oro, cuyo ajuar funerario da indicios de estar conectadas con un mundo excepcionalmente dilatado, en una red de relaciones e intercambios a escala continental. El o los difuntos parecen, además, haber estado relacionados con el ámbito marino por la abundancia de adornos en conchas. Quizá trabajos arqueológicos futuros esclarecerán la identidad de las personas que estuvieron vinculadas con la presencia de estas obras de tan lejanos y distintos orígenes. Por ahora, contamos con el hecho de que la región está a la orilla de lo que fue territorio tarasco y en el cruce de rutas naturales hacia los puertos marítimos de la desembocadura del Balsas o de la bahía de Zihuatanejo. Por tanto, es muy probable que estas piezas de procedencia sureña y quizá también las

I6. Donald W. Lathrap, "Relationships between Mesoamerica and the Andean Areas", Handbook of Middle American Indians, vol. 4 (1966): 273.

I7. Reyna Robles, "Esculturas, estelas y lápidas de la región del Balsas", 37I. 
4. Lanzón de Chavín. Dibujo retomado de Richard

L. Burger, Chavin and the Origins of Andean Civilization (Londres: Thames and Hudson, 1992),

fig. I4O.

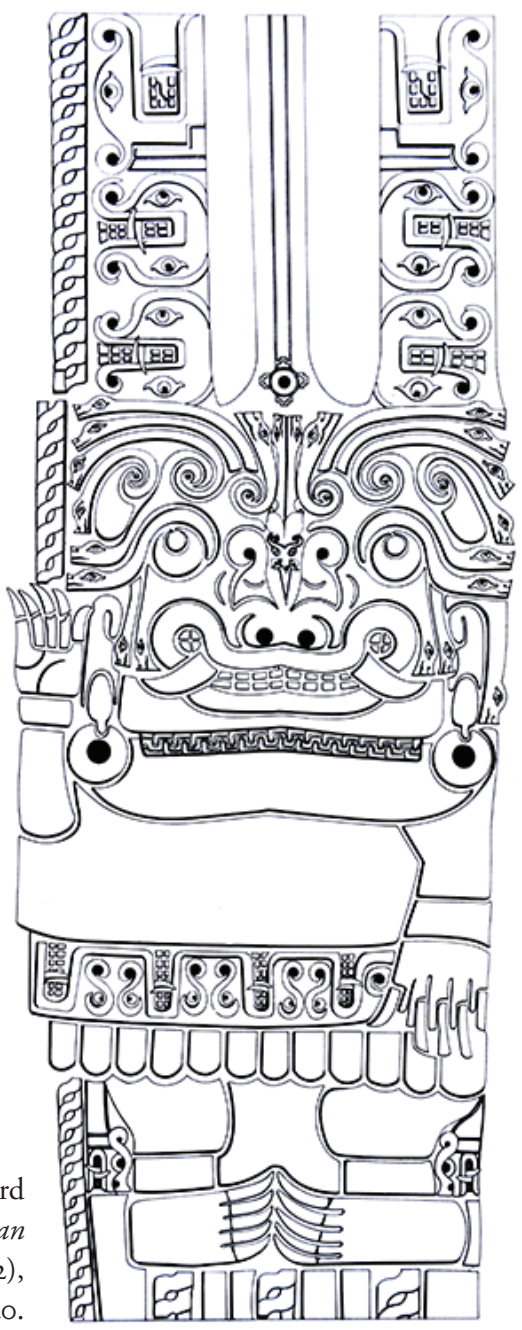

personas que las trajeron estuvieran involucradas en viajes marítimos a lo largo de las costas del Pacífico. ${ }^{18}$

18. Para una síntesis acerca de los contactos marítimos en épocas anteriores entre el Occidente y la costa ecuatoriana véase Allison C. Paulsen, "Patterns of Maritime Trade between South Coastal Ecuador and Western Mesoamerica, 1500 BC-60o AD", en The Sea in the PreColumbian World. A Conference at Dumbarton Oaks, October 26th and 27th, 1974, Washington, 
De perros pelones, buzos y Spondylus

¿Qué puede haber propiciado estos contactos marítimos? Tanto para Mesoamérica como para el mundo andino, viene a la mente el Spondylus. Desde tiempos remotos en ambos mundos, este bello bivalvo rojo, junto con la trompeta marina Strombus y otros géneros de gasterópodos, había conformado la mencionada díada del mullu-pututu. ${ }^{19}$ Este conjunto de conchas marinas de aguas calientes junto con la madreperla Pinctada mazatlanica y las de tinte como el Murex se distribuían desde el golfo de California hasta el de Guayaquil; ocupan fondos profundos por lo cual requieren el trabajo altamente especializado de buzos que logran bajar a pulmón libre a grandes profundidades. ¿Qué se sabe acerca de la eventual participación de los tarascos en estos contactos marítimos para la época que nos ocupa, más allá de la confluencia continental atestiguada en Placeres del Oro?

En México, durante el Epiclásico, tenemos, en dos lugares distintos, contextos arqueológicos en los cuales individuos del Occidente, algunos con evidencias de haber sido buzos, están relacionados con el trabajo de la concha marina, en especial el Spondylus y con el perro, en particular el perro pelón xoloitzcuintli.

En Michoacán, en la región de Zacapu, y más precisamente en el sitio de Guadalupe, en entierros del Epiclásico, junto con evidencias de un amplio uso de la concha, se han detectado casos de exóstosis auditivo en restos óseos. ${ }^{20}$ Esta deformación indica que esas personas habían sido buzos de agua profunda. En el lugar se ha reconocido, además, la presencia más antigua detectada hasta ahora del perro pelón. ${ }^{21}$

D.C., ed. Elizabeth P. Benson (Washington, D.C.: Dumbarton Oaks Research Library and Collections, I977), I4I-I60.

19. El uso ceremonial del Spondylus, por cierto asociado a vasijas con asa de estribo, ha sido reportado desde épocas muy tempranas tanto en la costa ecuatoriana (Valdivia) como en la ceja de la selva amazónica: Lathrap, El Ecuador antiguo, 25 y Francisco Valdez, "Mayo Chinchipe, el otro Formativo Temprano", Miscelánea Antropológica Ecuatoriana, segunda época, año I, núm. I (Guayaquil: Boletín de los Museos del Banco Central del Ecuador, 2008): 173-197. Para un estudio ampliamente documentado sobre el uso del Spondylus en el mundo andino, véase Mylène Bussy, Le Spondylus au Pérou et en Equateur à l'époque préhispanique, Mémoire de maîtrise d'Archéologie Précolombienne (Université de Paris I Panthéon-Sorbonne, I996-1997).

20. Arnauld, Carot y Fauvet-Berthelot, Arqueología de las Lomas en la cuenca lacustre de Zacapu, $\mathrm{I} 36$.

2I. En este caso se trata de restos de comida en un relleno: Gregory Pereira, "Arqueología de un lugar de pasaje hacia el inframundo", Trace, núm. 58 (diciembre, 20I0): I9-28; Raúl 
En Tula, gracias a los trabajos de Raúl Valadez Azúa, Blanca Paredes Gudiño y Bernardo Rodríguez Galicia, sabemos que, en una muy temprana ocupación alrededor de 650 de la era, llegó un grupo originario del Occidente. ${ }^{22}$ Estos migrantes trabajaban la concha marina y en particular el Spondylus. Trece de ellos, hombres y mujeres con exóstosis auditivo, murieron a la edad adulta y antes de su llegada a Tula habían sido buceadores de aguas profundas para recoger las preciadas conchas como el Spondylus. Además, trajeron consigo sus perros y nueve de ellos se enterraron con uno o varios de los 27 perros que se hallaron en este contexto funerario.

\section{El origen del perro pelón}

Antes de ahondar en el tema del Spondylus, es pertinente detenerse en la tradición que considera al perro como acompañante en el viaje de la muerte, bien sea al enterrar a las personas con sus perros, o al sepultar cuidadosamente al animal mismo, o depositar en la ofrenda funeraria su representación en barro.

Esta costumbre se remonta a tiempos muy antiguos en el Occidente. En Chupícuaro, siglos antes de la era actual, numerosos perros se enterraron como acompańantes o solos y se representaron en barro. ${ }^{23}$ En las ofrendas funerarias de las tumbas de tiro, en particular en Colima, abundan las imágenes del cánido. ${ }^{24}$ En el centro del país, esta tradición parece haberse respetado particularmente

Valadez Azúa y Gabriel Mestre Arrioja, Xoloitzcuintle, del enigma al siglo XXI (México: Artenación Editores, 2007), 33-35; Bernardo Rodríguez Galicia, Raúl Valadez Azúa, Grégory Pereira, Fernando Viniegra Rodríguez, Katiuska Olmos Rodríguez y Alicia Blanco Padilla, "Restos arqueozoológicos de perros (Canis familiaris) encontrados en el sitio de Guadalupe, estado de Michoacán", AMMVEPE I2, núm. 6 (200I): 199-209.

22. Raúl Valadez Azúa, Blanca Paredes Gudiño y Bernardo Rodríguez Galicia, "Entierros de perros descubiertos en la antigua ciudad de Tula", Latin American Antiquity, núm. IO-2 (junio, 1999): 180-200.

23. Muriel Porter, Excavations et Chupicuaro, Guanajuato, Mexico, Transactions of the American Philosophical Society 46, parte 5 (Filadelfia: American Philosophical Society, 1956), 537 .

24. María de los Ángeles Olay Barrientos, "La arqueología de Colima”, Arqueología Mexicana. Los tesoros de Colima, edición especial, núm. 9 (2002): 6-ıI; Guillermo García Oropeza, Fernando Benítez, Luis Ortiz Macedo, Beatriz Braniff, Alberto Díaz de Cossío y Luis González y González, Perros en las tumbas de Colima (Gobierno del Estado de Colima/Universidad de Colima), 1998. 
cuando hubo fuertes contactos con grupos del Occidente, como fue el caso en Tlatilco, pero también muchos siglos después en numerosas sepulturas teotihuacanas, así como en la mencionada ocupación temprana de Tula. ${ }^{25}$

Pero, hay más todavía. La colección de perros de Tula destaca por la cantidad de ejemplares encontrados y por la buena conservación de los restos, lo cual se debe al hecho de haber sido enterrados junto a sus amos y no proceder de relleno. Estas circunstancias han permitido establecer con claridad las características óseas de tres de las razas de perros que existieron en el México antiguo y que están presentes en la colección: el perro común de amplia distribución y mayor antigüedad; el tlalchichi de patas cortas y el famoso perro pelón xoloitzcuintli. ${ }^{26}$

Este último es de particular interés por el tema de las relaciones con Sudamérica. Se trata de una mutación genética (displasia ectodérmica autonómica dominante), caracterizada por una piel que permanece en estado embrionario y por ende sin pelo y por un desarrollo menor de la dentición. Las camadas siempre son mixtas, los pelones tienen en su acervo genético la piel con pelo y sin pelo. Lo particularmente interesante para el tema de las relaciones sobre grandes distancias que nos ocupa, es el hecho de que, por sus características genéticas, su presencia sólo puede explicarse mediante grupos humanos acompañados con sus perros pelones. ${ }^{27}$ Por ende, este can, singular tanto en Mesoamérica como en el mundo andino, es un testimonio fehaciente de estos antiguos intercambios, muy probablemente marítimos. Falta saber cuándo y en qué dirección se dio esta difusión del xoloitzcuintli de un lado al otro del continente.

Se supone generalmente que el perro es originario del Occidente de México hace algo más de 2000 años. Esta propuesta se basa en las tempranas representaciones del animal en las producciones artísticas, en el hecho de que su introducción en el centro del país parece deberse a individuos del Occidente, tal

25. Para mayores detalles sobre esta tradición en Mesoamérica, véase Carolyn Baus de Czitrom, Los perros de la antigua provincia de Colima (México: Instituto Nacional de Antropología e Historia, 1988), 25-26.

26. Valadez Azúa, Paredes Gudiño y Rodríguez Galicia, "Entierros de perros descubiertos en la antigua ciudad de Tula", I80-200; Raúl Valadez, "Perros pelones del México prehispánico", Arqueobios I, núm. 3 (diciembre, 2009): http:///www.arqueobios.org; Raúl Valadez, Christopher M. Götz y Velia V. Mendoza, El perro pelón, su origen, su historia (México: Universidad Autónoma de Yucatán/Universidad Nacional Autónoma de México-Instituto de Investigaciones Antropológicas), 2012.

27. Cabrero y Valadez, "El perro en el sitio arqueológico de Pochotitán, Jalisco", II-I5. 
como se documentó en Tula siglos después, así como en el papel preponderante que parece haber tenido dicha región en las relaciones con Sudamérica y, por último, por su presencia más difundida en la actualidad en esta parte del país.

Sin embargo, y a pesar de los notables avances que han tenido los estudios arqueozoológicos sobre este tema en México, en el ámbito continental el origen del perro lampiño sigue incierto. Para rastrear su historia y su dispersión a escala americana, se dispone esencialmente de dos tipos de evidencias: los restos óseos de mandíbulas y las representaciones artísticas. Las efigies más antiguas de perros conocidas hasta ahora se encuentran en dos culturas que presentan muchas afinidades entre sí: la de Tlatilco ${ }^{28}$ y la Chorrera de la costa ecuatoriana, pero en estas obras no hay indicios para distinguir si se trata o no del perro lampiño. ${ }^{29}$

Éste se puede reconocer en cierta medida cuando la piel presenta arrugas o está pegada a los huesos, o cuando se detalla la dentadura deficiente. En México, las representaciones en las que se puede apreciar al perro pelón corresponden a la cultura de las tumbas de tiro y, en particular, al arte de la fase Comala. Los artistas Comala que ejecutaron estas obras estaban familiarizados con los perros pelones y la singularidad genética de que en cada camada siempre hay uno o varios cachorros con pelo. Esto es lo que inspiró la obra emblemática de Colima que representa un par de cachorros abrazados conocidos como los "danzantes", uno con las arrugas y la piel pegada a los huesos que corresponden al pelón y el otro de complexión similar, pero sin estas características de la piel (fig. 5). ${ }^{30}$ Como veremos, más adelante, en esta misma época del Clásico

28. Entre las pequeñas figurillas sólidas, el perro acompaña a menudo a la mujer, mientras que entre las esculturas grandes huecas hay vasijas en forma de perro: Román Piña Chan, Tlatilco a través de su cerámica (México: Instituto Nacional de Antropología e Historia, 1958), lám. ıо; y hay ejemplares en los cuales el cánido porta una máscara humana: Román Piña Chan, Las culturas preclásicas de la cuenca de México (México: Fondo de Cultura Económica, 1955), 89, fig. 44. El tema del perro con máscara se encuentra también siglos después en el arte del estilo Comala: Baus de Czitrom, Los perros de la antigua provincia de Colima, $5 \mathrm{I}$.

29. Donald W. Lathrap (El Ecuador antiguo, 24-25, fig. 7) propone reconocer en una efigie Chorrera la representación más antigua del perro pelón y, por ende, ubicar el origen de este perro en Ecuador. Marion Schwartz cita otra efigie de perro con las mismas manchas oscuras sobre fondo claro, fechado hacia 600 antes de la era y procedente del sitio de Tembladera, en el valle de Jequetepeque de la costa norte de Perú (A History of Dogs in the Early Americas [New Haven: Yale University Press, 1997], I30-I3I), como antecedente de los perros enroscados sobre sí mismos de Colima, Monte Albán, Teotihuacan y Kaminaljuyú.

30. Valadez, Götz y Mendoza, El perro pelón, su origen, su historia, 87-88, fig. 23 a. 


\section{6} PATRICIA CAROT Y MARIE-ARETI HERS

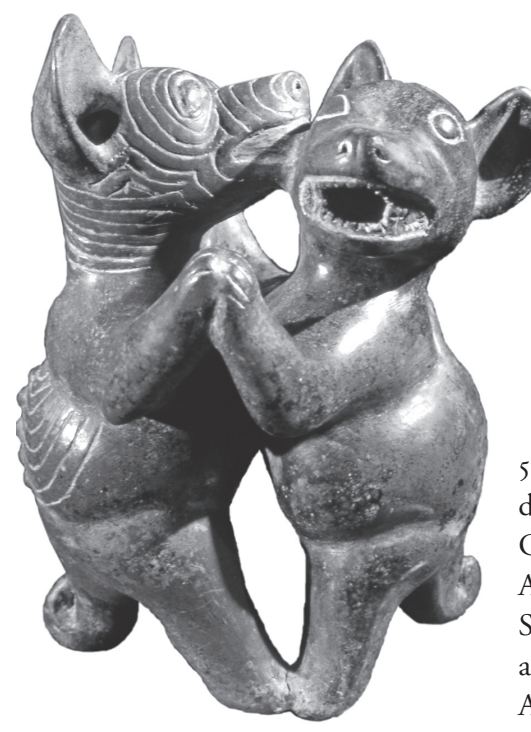

5. Pareja de perros, estilo Comala, Colima. Museo de las Culturas de Occidente María Ahumada de Gómez, Colima. Foto: Maribel Morales Rosales. Archivo Fotográfico Manuel Toussaint, IIE-UnAM. Secretaría de Cultura-INAH-Méx. "Reproducción autorizada por el Instituto Nacional de Antropología e Historia”.

Temprano, en Teotihuacan, artistas alfareros también representaron al perro pelón con la piel arrugada (fig. 6). . $^{3}$

En cuanto a los restos óseos del xoloitzcuintli, por ahora son todavía escasas las colecciones bien conservadas, estudiadas adecuadamente y con evidencia de su presencia.

Así, los más antiguos identificados hasta ahora son los casos mencionados y relativamente tardíos de Tula y de Guadalupe. Aún no se han encontrado sus restos óseos en el contexto de la cultura de las tumbas de tiro para confrontarlos con las esculturas, ${ }^{32}$ mientras que las colecciones de restos de perros encontrados en los entierros de Tlatilco y en Chupícuaro no han sido estudiadas con el propósito de identificar razas particulares. ${ }^{33}$ En Teotihuacan, solamente

3I. Claudia María López Pérez, "Cerámica”, en Teotihuacan. Ciudad de los Dioses, catálogo de la exposición (México: Instituto Nacional de Antropología e Historia, 2009), I3I-I92.

32. En el sitio de Pochotitán, perteneciente a la cultura de las tumbas de tiro, se ha podido documentar el uso ritual de los perros, pero todos los ejemplares eran animales comunes mesoamericanos: Teresa Cabrero y Raúl Valadez, "El perro en el sitio arqueológico de Pochotitán, Jalisco", $A M M V E P E$ 20, núm. 4 (2009): 85-94.

33. Valadez, Götz y Mendoza, El perro pelón, su origen, su historia, I80-I8I; Ticul Álvarez, "Restos óseos de las excavaciones de Tlatilco, Estado de México", Apuntes para la Arqueología, núm. I5 (1976): 3-18. 


\section{Vasija-efigie de perro xoloitzcuintli, Teotihuacan. Colección Museo Amparo. Foto: Carlos Varillas.}

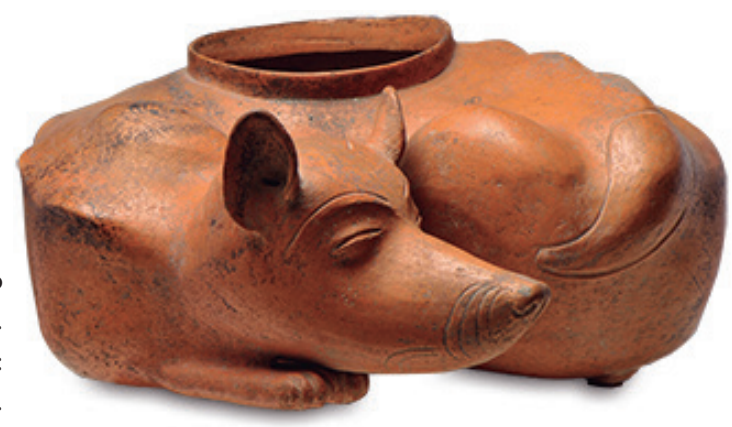

algunas de las colecciones de perros han sido estudiadas por especialistas en la materia y en ellas no se han encontrado evidencias del perro lampiño, contradiciendo la información transmitida por las esculturas en Anaranjado Delgado ya mencionadas. ${ }^{34}$

En el caso del mundo andino, la documentación arqueozoológica también es reducida, pero apunta hacia una presencia antigua del perro pelón, en un contexto particularmente solemne. Se reporta su presencia entre los bienes depositados en las celdas de la galería de las ofrendas del Viejo Templo de Chavín de Huantar. Dicha galería subterránea se encuentra en la plataforma que cierra la plaza circular hundida. Desde esta plaza se accedía al templo y a la galería del imponente lanzón monolítico y en el centro se levantaba el Obelisco Tello. Hacia 850 a.C., cuando se terminó de construir la plataforma y las instalaciones del atrio circular, la galería se selló con las ofrendas que habían traído dignatarios de diversas provincias lejanas para una solemne ceremonia representada quizá en los frisos con procesiones de guerreros, sacerdotes y jaguares que aún se conservan en el patio. Además de brebajes vertidos en los botellones de asa de estribo y otros bienes preciados servidos en las vasijas, así como

34. Según Valadez y Mestre Arrioja, Xoloitzcuintle, del enigma al siglo XXI, 35, los ejemplares de perros pelones encontrados en la zona corresponden a la ocupación posterior a la caída de la gran metrópoli, y se fechan entre los siglos viII y xvi. Sin embargo, Laurette Séjourné reporta la presencia de numerosos perros depositados en cajetes en ofrendas a construcciones y en sepulturas (Arqueología de Teotihuacan. La cerámica [México: Fondo de Cultura Económica, I966], 235); Teotihuacan, capital de los toltecas (México: Siglo XXI, 1994), 49; Un palacio en la ciudad de los dioses (México: Fondo de Cultura Económica, 2002), 64; en un análisis de algunos de estos restos de perros se sugiere la presencia de xoloitzcuintli (Un palacio en la ciudad de los dioses, 66). 
la parafernalia para el uso de alucinógenos, se depositaron restos de animales. Entre éstos, se reconocen dos especies de perros, la mayoría de ellos pertenecientes a la especie de Canis familiaris del tipo inca (Canis ingae Tschudii, I844), conocido actualmente como el perro ovejero. Pero también se distingue por la mandíbula, el perro sin pelo, el qala como se llama en la costa peruana, el xoloitzcuintli mexicano. ${ }^{35}$ Este hallazgo es importante para el tema de este trabajo no solamente por su antigüedad sino por el contexto de esta ceremonia que convocó a peregrinos procedentes de tierras lejanas para presentarse ante el Lanzón en rituales donde se tañían los grandes Strombus y se ofrendaba el precioso mullu, la concha roja de Spondylus. No sobra recordar que desde tiempo atrás han llamado la atención las similitudes entre el arte y la religión del Chavín y el olmeca del cual participó, por cierto, Tlatilco, que ya se mencionó por las muy tempranas representaciones y entierros de perros.

En cuanto a las representaciones del perro lampiño en el mundo andino, las primeras habrían pertenecido a las culturas Virús y Nazca de Perú, que datan de los primeros siglos de la era actual y son, por ende, contemporáneas de las obras del estilo Comala de la cultura de las tumbas de tiro y de las efigies en Anaranjado Delgado de Teotihuacan. ${ }^{36}$ Sin embargo, como se ha visto, las representaciones de perros más antiguas se remontan a muchos siglos antes, en tiempos de la cultura Chorrera y de la de Tlatilco. Reconocer o no en ellas la imagen del perro pelón no deja de ser algo bastante subjetivo. Es prudente por tanto dejar abierta por ahora la cuestión del lugar de origen y la época de su difusión, y quedarse con lo que parece mejor documentado: la estrecha relación de este perro en México con poblaciones del Occidente y su carácter como testigo de las relaciones continentales varios siglos antes de esta era. Considerado mexicano en México y peruano en Perú, originario del Occidente de México, de la costa ecuatoriana o de los Andes peruanos, lo cierto es que no pudo haberse expandido en el continente sin la participación humana.

35. Marion Schwartz, A History of Dogs in the Early Americas (New Haven: Yale University Press, 1997): 133; Raúl Valadez cita el único caso de una momia tardía del altiplano boliviano: Valadez y Mestre Arriola, Xoloitzcuintle, del enigma al siglo XXI, 45; Valadez, Götz y Mendoza, El perro pelón, su origen, su historia, 4I. Parece no conocer el caso de Chavín de Huantar: Luis Guillermo Lumbreras, Chavín; excavaciones arqueológicas, t. I (Lima: UAP Universidad Alas Peruanas, 2007), 318, fig. 236.

36. Valadez, Götz y Mendoza, El perro pelón, su origen, su historia, 55-57, 62-66, figs. 30 y 3I. Por su parte, Schwartz (A History of Dogs in the Early Americas, I33) ubica las primeras representaciones de perros con la piel arrugada pelona en el mundo andino, en la cultura moche alrededor de 500 de la era actual. 
En las balsas, probablemente desde el primer milenio antes de la era actual, el perro pelón acompañaba a marineros, a comerciantes, a los aventureros del mar que iban en pos del Spondylus entre otros bienes preciados.

\section{El comercio maritimo del Spondylus a finales del primer milenio}

Como se señaló al inicio, la díada mullu-pututu apareció muy temprano en el contexto de un amplio sistema de intercambios panandinos. Luego llegó a ser un tema importante del arte del estilo Chavín y perduró a lo largo de milenios hasta la llegada de los españoles. El Spondylus fue objeto de un marcado interés económico y ceremonial por parte de las más diversas poblaciones andinas del antiguo Perú, que tenían que proveerse desde la lejana costa ecuatoriana de la bella concha, la cual no podía darse en las aguas frías de la corriente de Humboldt. En piezas enteras, recortadas en ornamentos y máscaras, o trituradas en polvo, estas conchas se consideraban el alimento favorito de los dioses, se apreciaban más que el oro mismo y llegaron a servir como una especie de moneda, en particular para los mercaderes de la costa ecuatoriana. ${ }^{37}$

En Mesoamérica, el Spondylus no parece haber alcanzado esa preponderancia simbólica que tuvo en el mundo andino, o, más bien, no ha sido objeto de estudios tan amplios y específicos. Sin embargo, su valor ceremonial y simbólico es indudable. La díada Spondylus-Strombus se ha reconocido entre los motivos que definen el ámbito sagrado de las aguas del inframundo donde se expande la gran serpiente emplumada del Templo de Quetzalcóatl de Teotihuacan..$^{38}$ Y, en diversos contextos de esta gran metrópoli, el Spondylus, y en particular la especie princeps, aparece en numerosas ofrendas, específicamente en las que acompañaron las solemnes ceremonias de consagración que tuvie-

37. Además de los autores citados en la nota I9, entre la abundante literatura sobre el Spondylus en el mundo andino, véase, por ejemplo: John V. Murra, "El tráfico de mullu en la costa del Pacífico", Primer Simposio de Correlaciones Antropológicas, 265-274; Jorge G. Marcos Pino, Ecuador antiguo. Las sociedades de la costa del área septentrional andina 300 a.C.-I50o d.C., Ancient Ecuador. Coastal Societies of the Northern Andean Region (Guayaquil: Banco del Pacífico/Museo Arqueológico, 1993); Jorge G. Marcos Pino, Los 10000 años del antiguo Ecuador. La historia de sus pueblos a través de su arte y su ciencia (Guayaquil: Museo Arqueológico y de Arte Contemporáneo, 2006).

38. Donald W. Lathrap, "Complex Iconographic Features Shared by Olmec and Chavín and some Speculations on their Possible Significance", en Primer Simposio de Correlaciones Antropológicas, 3 IO. 
ron lugar en espacios tan significativos como el Templo de Quetzalcóatl y la Pirámide de la Luna. Aparece bajo la forma de piezas enteras, de valvas rebajadas y pulidas, a veces grabadas, de pendientes y cuentas, en particular como pendientes rectangulares adheridos a las capas cortas con las cuales se habían revestido las víctimas del sacrificio. Siglos después, la preciada concha roja se siguió utilizando en la confección de atuendos con alto valor simbólico como es el caso de la famosa coraza ceremonial encontrada en el Palacio Quemado de Tula. Estudios más amplios sobre este bivalvo permitirán apreciar mejor a futuro el indudable valor simbólico de éste y su larga trayectoria en la historia mesoamericana.

Por ahora, se sabe, gracias a los trabajos de José Carlos Beltrán Medina en la costa del Occidente de México (en Playa del Tesoro, Colima y Punta Mita, Nayarit) ${ }^{39}$ y de Jorge Marcos y Presley Norton, en la Isla de la Plata en la costa ecuatoriana, ${ }^{4 \circ}$ que si bien la recolección del Spondylus tiene una muy larga historia en ambas costas, hacia finales del primer milenio se desencadenó un fenómeno muy complejo cuyo origen habría de buscarse más al sur.

Como lo propone Anne Marie Hocquenghem, el auge considerable en la explotación del Spondylus princeps estaría ligado al desarrollo tecnológico del bronce arsenical, propiciado por los sicanes del departamento de Lambayeque, documentado por los trabajos de Izumi Shumada y por sus propias investigaciones en los valles de los ríos Piura, Chira y Tumbes. El dominio del bronce permitió a la elite sicán asentar un gran poderío, extender considerablemente la frontera agrícola, favorecer el crecimiento poblacional y acumular riquezas con base en una extensa red de bienes suntuarios. Entre éstos figuran algunos de muy lejana procedencia como la turquesa y, en particular, la especie más espectacular y preciada del Spondylus, el princeps, de aguas profundas, con el color más acentuado y la forma más regular.

Esta especie es distinta del Spondylus calcifer, el cual es más accesible por hallarse en menor profundidad, pero la forma es irregular y el color es de tono menos intenso. La distinción entre estas dos especies es improbable cuando se trata de objetos trabajados para los cuales la concha ha sido recortada, rebaja-

39. José Carlos Beltrán Medina, Comentarios arqueológicos sobre el antiguo puerto de Salagua (México: Gobierno del Estado de Colima/Universidad de Colima/Consejo Nacional para la Cultura y las Artes, 1994); La explotación de la costa del Pacifico en el Occidente de Mesoamérica y los contactos con Sudamérica y con otras regiones culturales, Cuadernos del Seminario Nayarit: Región y Sociedad (Tepic: Universidad Autónoma de Nayarit, 200I).

40. Marcos Pino, Los Io 000 años del antiguo Ecuador. 
da y pulida y, a menudo, las identificaciones ofrecidas en la literatura arqueológica son dudosas. Al encontrar en la Isla de la Plata grandísimos depósitos de Spondylus princeps se supuso, en un principio, que ese bien tan buscado por los sicanes de Batán Grande provenía de ahí. Sin embargo, estudios de biología marina aportaron datos sorprendentes: la relativa escasez de Spondylus princeps en los fondos rocosos de la isla. Por tanto, la Isla de la Plata no habría sido preponderantemente el lugar de recolección de tan preciado bien, sino un importante puerto comercial y de almacenamiento para responder a una poderosa demanda por parte de las cortes que se sucedieron al sur, en tierras peruanas.

La importancia que concedían los señores sicanes al Spondylus princeps y, por ende, su papel en el gran auge de su explotación, concuerda con la interpretación que propone Alana Cordy-Collins de la leyenda relativa a la llegada de Naymlab y el esplendor de su corte reportada en la tradición chimú. Según esta investigadora sería, más que una leyenda, la referencia a una realidad histórica anterior al imperio chimú. ${ }^{41}$ Serían los señores sicanes quienes habrían introducido las funciones cortesanas del fonga sigde o proveedor de conchas prestigiosas de Spondylus princeps, y encargado, en tiempos del dominio chimú, de esparcirlas reducidas en polvo rojo ante los pies del rey de Chan Chan, junto con el pita zofi que soplaba el Strombus. Dicha investigadora basa su propuesta en un estudio iconográfico de piezas sicanes en las cuales aparece representado el arriesgado trabajo de los buzos bajando a las profundidades, amarrados con una cuerda a una balsa con vela como las usaron los afamados navegantes ecuatorianos $\mathrm{y}$, a veces, provistos del instrumento cortante para desprender el bivalvo del fondo rocoso.

Así, la demanda acrecentada de Spondylus princeps en el mundo andino habría propiciado los contactos marítimos con otras áreas de la provincia malacológica que va de la costa ecuatoriana al golfo de California, y en particular, con el Occidente de México. Y, en efecto, en los lugares estudiados por José Beltrán en las costas mexicanas está presente esta especie tan preciada; además, en los contextos arqueológicos se reconoce por estos tiempos de finales del primer milenio, un gran auge en su recolección, comercio y almacenamiento. En Punta Mita, Nayarit, podría haber existido una colonia de buceadores de

4I. Alana Cordy-Collins, "Fonga Sigde, Shell Purveyor to the Chimu Kings", en The Northern Dynasties Kingship and Statecraft in Chimor. A Symposium at Dumbarton Oaks, I2th and I3th October 1985, eds. Michael E. Moseley y Alana Cordy-Collins (Washington, D.C.: Dumbarton Oaks Research Library and Collection, 1989), 393-417. 
la costa de Manabí a juzgar por la presencia de anclas como las que usaban en las balsas oceánicas y de pesos para el buceo idénticos a los encontrados en la Isla de la Plata. Junto con estos expertos buceadores, habrían venido también especialistas en metalurgia y tejidos. ${ }^{42}$

Cabe recordar el famoso testimonio del piloto Bartolomé Ruiz contratado por Pizarro, quien describió la balsa oceánica que abordó cerca de la Bahía de San Mateo, cercana a Manta, perteneciente al señorío de Salangome. Después de enumerar las riquezas en objetos de oro y plata, en vasijas, en textiles refinados, y otros bienes, señala que para rescatar todos estos bienes, los mercaderes traían "unas conchas de pescado de que llos hazen quentas coloradas como corales y blancas que trayina casi el navio cargado de ellas". ${ }^{43}$

\section{Los navegantes ecuatorianos, sus balsas y su poder}

Todavía en el siglo pasado, seguían en servicio de cabotaje las últimas balsas de gran tonelaje, similares a las descritas por varios testigos del periodo colonial y que habían hecho la fuerza de los poderosos mercaderes de la época Manteña-Huancavilca. Con los palos de balsa (Ochroma lagopus) anudados con henequén y la caña guadúa (Guadua angustifolia) para los altos, disponían de una amplia embarcación de 25 a 30 metros de largo para unas 30 personas y mercancías, insumergible y duradera, provista de una gran vela de algodón, de un cobertizo ligero y sólido, y dotada, en lugar del timón, del sistema de tablas "guaras" colocadas verticalmente entre los palos en la proa y en la popa que se alzaban o bajaban para orzar eficientemente. ${ }^{44}$ Con estas balsas podían ir costeando, pero también avanzar mar adentro sobre grandes distancias según lo imponían los vientos, las corrientes y los peligros de las marejadas y de las puntas rocosas. ${ }^{45}$ Este arte de navegar, que habían adquirido los marineros ecuatorianos a lo largo de milenios de viajes y exploraciones, ha sido

42. Marcos Pino, Los Io 000 años del antiguo Ecuador, 44.

43. Marcos Pino, Los 10000 años del antiguo Ecuador, 56-58.

44. Marcos Pino, Los Io 000 años del antiguo Ecuador, 36, 79; Marcos Pino, Arqueología de la Antigua Provincia de Manabi/The Archaeology of the Ancient Province of Manabi (Guayaquil: Ediciones Banco Central del Ecuador, 2000): 18-26.

45. Beltrán, Comentarios arqueológicos sobre el antiguo puerto de Salagua, 26. 
ampliamente reconocido y, en estudios recientes, comparado con el de los polinesios, esos otros grandes navegantes en balsas del Pacífico. ${ }^{46}$

\section{La efigie del buceador como emblema de esta red de intercambios continentales}

Ante las evidencias de intercambios continentales, es legítimo buscar en las expresiones artísticas eventuales referencias a los personajes involucrados en estos contactos marítimos, como serían los marineros, los mercaderes o los buceadores. Es lo que propone Marcelo Villalba al encontrar en el mundo andino y en Mesoamérica las representaciones en barro de lo que se llama comúnmente en Ecuador y en Colombia un "canastero" o también mercaderviajero: un personaje masculino, desnudo, sin más vestimenta que un taparrabo, sentado sobre el suelo, con las piernas cruzadas, las manos sobre las rodillas, y con una canasta o recipiente en la espalda. ${ }^{47}$

$\mathrm{Al}$ encontrar esta figura estereotipada en la costa ecuatorial (desde la época de transición entre las culturas Chorrera y Tolita [fig. 7a], luego la Jama-Coaque y hasta el periodo de Integración de las tumbas huancavilca), en las regiones colombianas de Calima (fig. 7b) e interandina ecuatoriana, así como en Mesoamérica, Villalba propone reconocer en ella el emblema de una especie de gremio cerrado que funcionaba en el ámbito local, regional y extrarregional, y que pervivió largo tiempo. Pero ¿por qué, entre los personajes que formaban parte de la esfera exclusiva del intercambio a larga distancia, se habría escogido como emblema a quien a primera vista sería un simple cargador casi desnudo? Marcelo Villalba deja esta pregunta en cierta medida sin respuesta, pero, al observar con detenimiento las dos decenas de vasijas-efigies mesoamericanas publicadas hasta ahora y ejemplares sureños, es evidente que no se

46. Con base en evidencias botánicas y lingüísticas, la costa ecuatoriana y sus hábiles mercaderes balseros se han considerado como la opción más plausible en eventuales contactos de los polinesios con el continente americano, en particular hacia finales del primer milenio: Richard Scaglion y María Auxiliadora Cordero, "Did Ancient Polynesians Reach the New World? Evaluating Evidence from Ecuatorian Gulf of Guayaquil", en Polynesians in America. Pre-Columbian Contacts with the New World, eds. Terry L. Jones, Alice A. Storey, Elizabeth A. Matisoo-Smith y José Miguel Ramírez-Alinga (Nueva York: Altamira Press, 20I2), I7I-I93. 47. Marcelo Villalba, “¿Canasteros o comerciantes?”, en Catálogo de la Sala de Arqueología (Quito: Museo Nacional del Banco Central del Ecuador, 1996), 58-7I. 

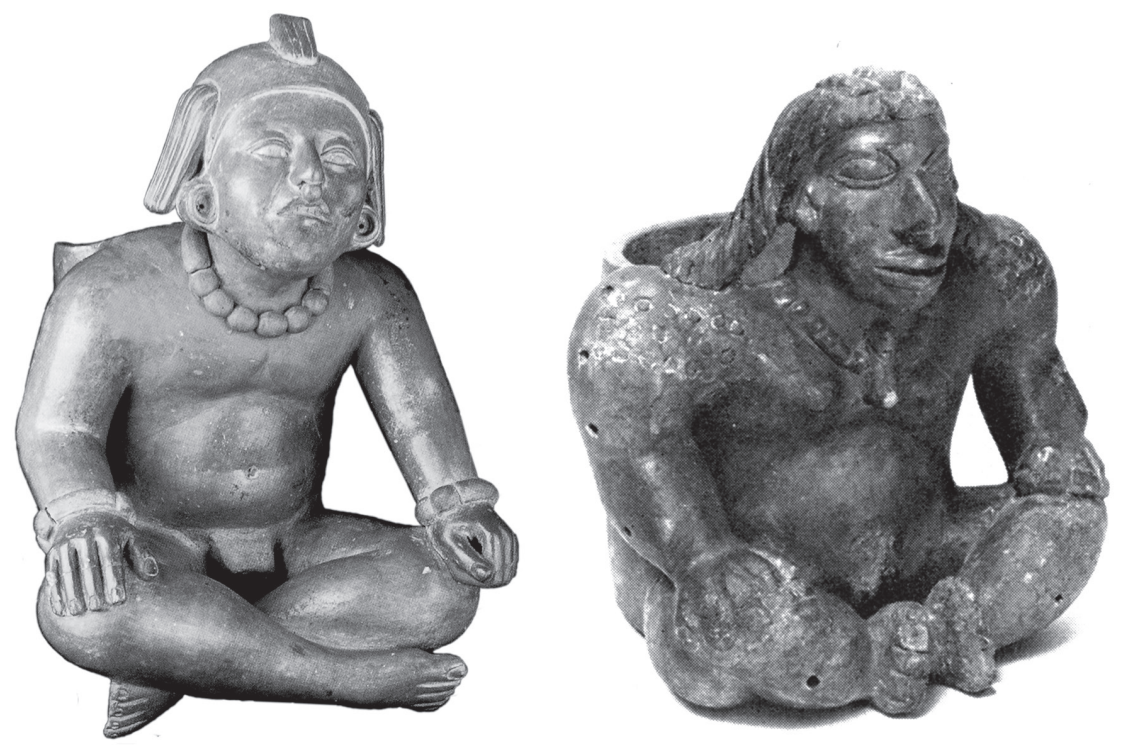

7. Vasijas-efigie a) transición Chorrera-Tolita. Tomada de Santiago Ontanedo, Las antiguas sociedades precolombinas del Ecuador. Un recorrido por la Sala de Arqueología del Museo Nacional (Quito: Banco Central del Ecuador, 20Io), 9I; b) Calima, cultura Ilama. Instituto Colombiano de Antropología, Bogotá. Tomada de Álvaro Soto Olguín, L'Art colombien à travers les siècles (París: Petit Palais, 1975), fig. I03.

trata de un humilde cargador sino del especialista que bajaba a las profundidades de los mares para conseguir las preciosas conchas de Spondylus.

Lo primero que llama la atención en las efigies son, en efecto, las proporciones singulares del cuerpo que se pueden apreciar por la desnudez del personaje. Tiene el pecho muy ancho y la musculatura de los hombros y brazos notablemente desarrollada, lo cual delata una vida dedicada a un esfuerzo físico prolongado y especializado, como podría ser el del nadador braceando en las profundidades (figs. 8-I4). Al respecto es interesante apuntar que los restos óseos de los buceadores identificados en Tula ya mencionados, además de la exóstosis auditiva, presentaban índices de estrés, desgaste y robusticidad. ${ }^{8}$

48. Blanca Paredes Gudiño, "El Occidente de México en la conformación de la sociedad tolteca”, en Tradiciones arqueológicas, ed. Efraín Cárdenas García (Zamora, Mich.: El Colegio de Michoacán/Gobierno del Estado de Michoacán, 2004), n. 4, 336. 
8. Vasija-efigie, Teotihuacan, Museo Nacional de Antropología e Historia. Tomada de Eduardo Matos Moctezuma, Teotihuacan: la metrópolis de los dioses (Barcelona: Lunwerg, I990), fig. 34. Secretaría de

Cultura-INAH-Méx. "Reproducción autorizada por el Instituto Nacional de Antropología e Historia”.

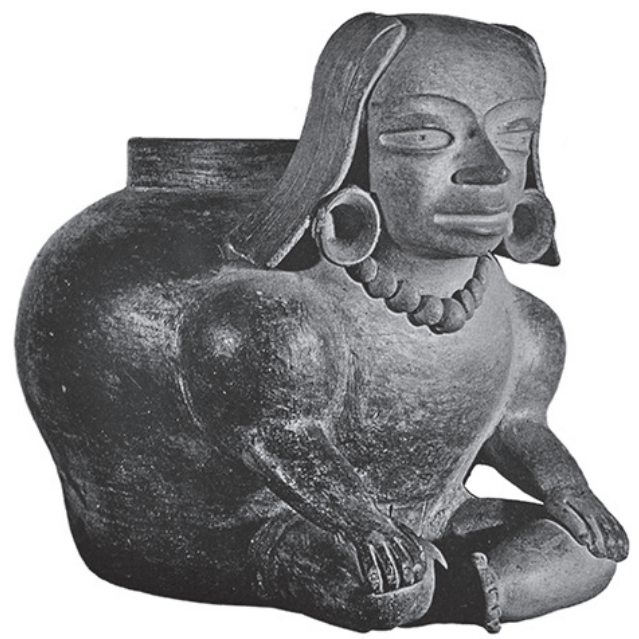

A menudo, a pesar de la aparente juventud del personaje, la cara está marcada por surcos que bajan de los lagrimales hasta las comisuras de la boca (figs. IO-I2) y, a veces, subrayan también los párpados (figs. I2 y I3), aparentando el esfuerzo de inflar las mejillas para retener el mayor tiempo posible el aire en los pulmones. ${ }^{49}$

Seis de estas efigies presentan además un par de aros que parecen haber sido objetos de uso práctico (figs. 9-II, I3 y I4). Se detallan claramente los cordones amarrados alrededor de la cabeza que atan estos anillos y los mantienen en lo alto de la frente. Es más, en un caso se puede apreciar cómo los cordones están fijos a los aros por medio de ganchos (fig. I4b). Podría tratarse de anteojeras para mejorar la visibilidad muy baja en la penumbra de las pro-

49. Solamente en un caso (fig. I5) estos surcos podrían corresponder a un anciano porque están acompańados de pómulos muy pronunciados y dos dientes que se asoman en la boca entreabierta. Pero aun en este caso, la evidente juventud y fortaleza del cuerpo contradicen los signos de vejez. Véase Alfred V. Kidder, Jesse D. Jennings y Edwin M. Shook, Excavations at Kaminaljuyu, Guatemala (Washington, D.C.: Carnegie Institution of Washington, 1946), fig. I94b; Teotihuacan. Art from the City of the Gods, eds. Kathleen Berrin y Esther Pasztory (Londres: Thames and Hudson, 1993), núm. de cat. 160; Muriel Porter, The Aztecs, Maya, and Their Predecessors. Archaeology of Mesoamerica (Nueva York: Academic Press, 1993), fig. 6.3.e. Agapi Filini lo publica como efigie de "el Viejo Dios del Fuego", en The Presence of Teotihuacan in the Cuitzeo Basin, Michoacan, Mexico. A World-system Perspective, International Series I279 (Óxford: BAR, 2004), fig. 3.3.b. 


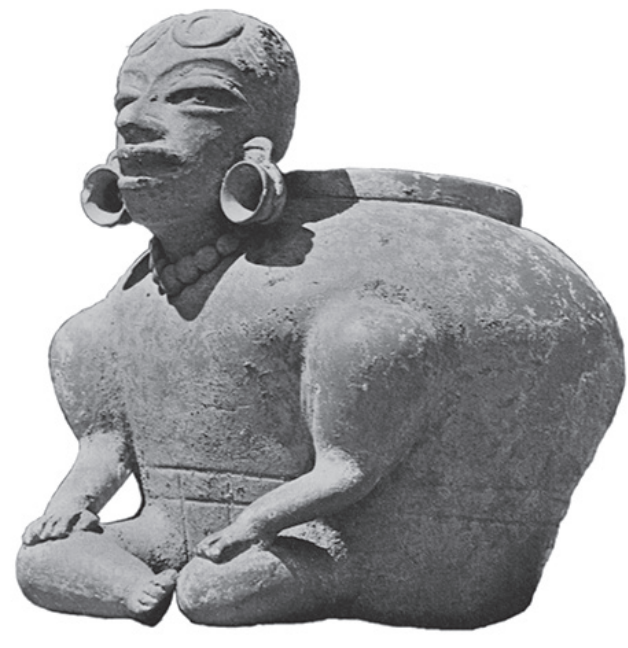

9. Vasija-efigie, Teotihuacan, Museo Anahuacalli. Tomada de Museo Diego Rivera-Anahuacalli (México: Comité Organizador de los Juegos de la XIX Olimpiada, I968), 35. Secretaría de Cultura-INAH-Méx. "Reproducción autorizada por el Instituto Nacional de Antropología e Historia”.

fundidades y los recovecos de los fondos rocosos. Los aros se habrían recortado de conchas a las cuales se habrían adherido lentes de hojas de mica. Tales pares de aros de concha sobre la frente y los discos de mica se han encontrado en los ajuares funerarios de Teotihuacan, de Tres Cerritos y de Huandacareo en Michoacán..$^{50}$ Entre las diversas representaciones de los buscadores de

50. Séjourné (Arqueología de Teotihuacan, 229) señala la presencia de discos de mica entre los abundantes objetos de este material asociados a los bultos funerarios y otras sepulturas (Teotihuacan, capital de los toltecas, 253; Un palacio en la ciudad de los dioses, 6I-62), y relaciona los anillos de concha con los círculos a modo de lentes que aparecen con frecuencia en los atuendos de los personajes importantes teotihuacanos; Filini, The Presence of Teotihuacan in the Cuitzeo Basin, Michoacán, 70-71, fig. 5.I8; Angelina Macías Goytia, "Tres Cerritos en el desarrollo social prehispánico de Cuitzeo”, tesis doctoral (México: Universidad Nacional Autónoma de México-Instituto de Investigaciones Antropológicas, 1997), 342 y Huandacareo, lugar de juicios, tribunal, Colección Científica (México: Instituto Nacional de Antropología e Historia) I49 y 202, fig. 60; Beltrán, La explotación de la costa del Pacífico en el Occidente de Mesoamérica, 40. Para la estrecha relación de la mica con el ámbito del poder, los procesos de trabajo y de uso, y su presencia en enclaves teotihuacanos como Kaminaljuyú o Tres Cerritos, véase el importante trabajo de Edgar A. Rosales y Linda Manzanilla, "Producción, consumo y distribución de la mica en Teotihuacan. Presencia de un recurso alóctono en los contextos arqueológicos de dos conjuntos arquitectónicos: Xalla y Teopancazco", en Producción artesanal y especialización en Mesoamérica; áreas de actividad y procesos productivos, eds. Linda Manzanilla y Kenneth G. Hirth (México: Universidad Nacional Autónoma de México-Instituto de Investigaciones Antropológicas, 20II), I3I-I46. 

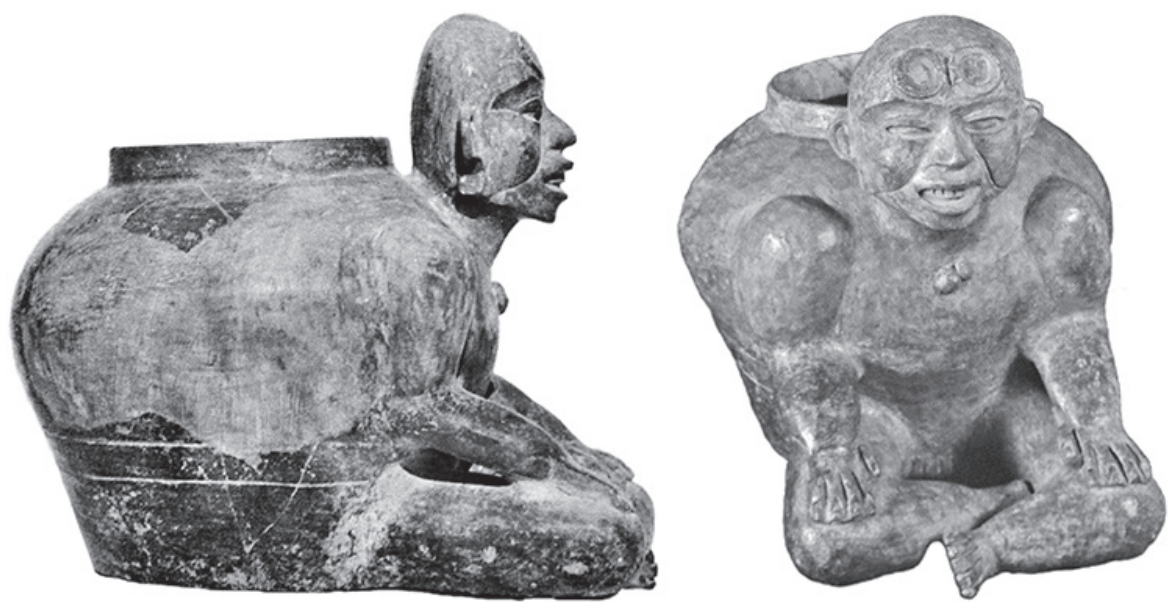

Io. Vasija-efigie, Tetitla, Teotihuacan, Museo Nacional de Antropología; a) tomada de Séjourné, Teotihuacan, capital de los toltecas (vid supra n. 34), I9I y b) tomada de López Pérez, "Cerámica" (vid supra, n. 31), I36. Secretaría de Cultura-INAH-Méx. "Reproducción autorizada por el Instituto Nacional de Antropología e Historia”.

Spondylus que se han encontrado en el mundo andino destaca un buzo chimú de plata en el que la figura tiene entre las manos una concha, lleva a la cintura la cuerda que lo ata a la balsa y tiene puestos grandes aros sobre los ojos (fig. 15).

¿Serán estos anillos, emblema del buzo, los que inspiraron las famosas anteojeras de Tláloc como símbolo de la visión más allá de lo cotidiano, de la visión que trasciende lo aparente? ${ }^{\text {II }}$ La experiencia extraordinaria de quien desciende al silencio de las oscuras aguas, a las profundidades del abismo o inframundo, la de aquel que penetra en otro mundo, el de los antepasados, el del origen.

A pesar de su desnudez, el personaje suele llevar algunos adornos que evocan cierto rango, como son las grandes orejeras tubulares, en algún caso en forma de caracol o un collar de cuentas de concha (fig. I2). A veces, lleva dos extrańas protuberancias esféricas a ambos lados de la cabeza cuyo sentido no es claro (figs. I2 y 13). Quizá sean conchas adheridas al pelo. Pero la relación con éstas resulta más evidente en el caso de dos ollas que llevan incisos

5I. Séjourné (Teotihuacan, capital de los toltecas, 253) apunta que los anillos a modo de lentes asociados a Tláloc "podrían simbolizar la visión interna que atraviesa la opacidad de las apariencias". 


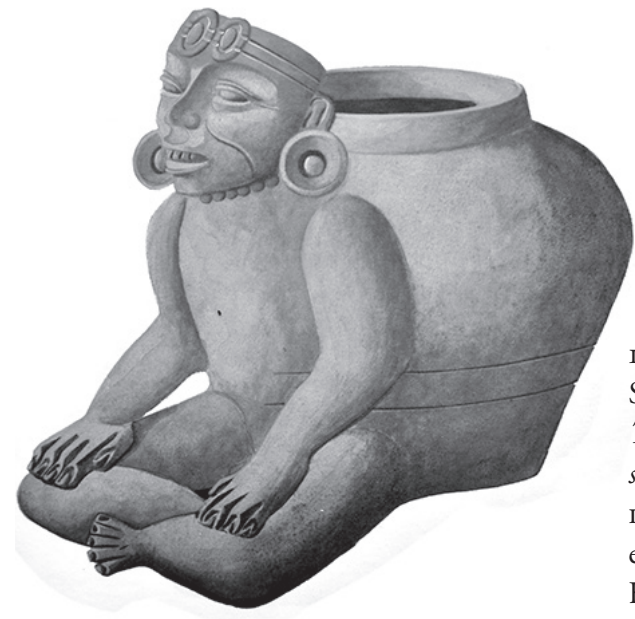

II. Vasija-efigie, Teotihuacan, Colección Stavenhagen. Tomada de Séjourné, Teotibuacan, capital de los toltecas (vid supra n. 34), 177. Secretaría de CulturaINAH-Méx. "Reproducción autorizada por el Instituto Nacional de Antropología e Historia”.

grandes bivalvos: se trata del ejemplar encontrado en Kaminaljuyú (fig. 16) y el de Toluca (fig. 17). Las ollas, originalmente cerradas con una tapa, contenían las preciosas conchas sacadas del fondo del mar.

La relación del personaje con la olla no es la de un simple cargador, entre ellos se complementan indisolublemente. A diferencia del cargador, la figura no está de pie ni encorvada ni lleva el mecapal para sostener la carga. La olla prolonga el cuerpo del personaje, y la doble línea incisa que rodea la base del recipiente continúa en la cintura de éste sin constituir una atadura real y eficaz para transportar la olla. La fusión es más íntima puesto que la cabeza del personaje corresponde a la tapa de la olla (figs. I4a y I4b) o en el caso de una variante, el cuerpo es la olla misma y los brazos y piernas son pequeños apéndices de un personaje sentado en cuclillas..$^{22}$

En Mesoamérica esta efigie no fue adoptada y recreada por pueblos costeros, sino en la gran metrópoli teotihuacana, centro de peregrinaciones y lugar por excelencia de los intercambios de bienes y saberes. Además, las imáge-

52. Kidder, Jennings y Shook, Excavations at Kaminaljuyu, Guatemala, I46, fig. I95b; Eduard Seler, Collected Works in Mesoamerican Linguistics and Archaeology, eds. y trads. Eric S. Thompson y Francis B. Reihardson, vol. VI (Culver City, California: Labyrinthos, 1990), pl. LIII-3; Eduardo Matos Moctezuma, Teotihuacan: la metrópolis de los dioses (Barcelona: Lunwerg, 1990), fig. 35; López Pérez, "Cerámica”, I37. 
nes se elaboraron en la vajilla más emblemática de su comercio, el Anaranjado Delgado.53

La gran mayoría de las piezas proceden de la metrópolis, aunque pocas tienen un contexto arqueológico preciso, otras provienen de tres lugares que mantuvieron fuertes relaciones con ella. Una fue encontrada en las excavaciones en Kaminaljuyú, Guatemala, y ha sido restaurada y ampliamente estudiada. ${ }^{54}$ Para las dos efigies procedentes del estado de Puebla, no existe información de su contexto.5

El ejemplar encontrado en Tres Cerritos, Michoacán, reviste mayor interés para este trabajo. ${ }^{56}$ El sitio se encuentra en la cuenca del lago de Cuitzeo que en el Clásico Temprano participó de la fase Loma Alta de la antigua historia purépecha, la cual, como se mencionó arriba, floreció en estrecha relación con Teotihuacan; ejemplo de ello es la presencia característica del talud-tablero.

La efigie formaba parte de una ofrenda depositada en una oquedad de la roca bajo el piso de la plaza Norte donde varios entierros contenían los pares de anillos de concha..$^{57}$ En esta plaza se han encontrado abundantes objetos en concha.

Una efigie se encontró en un lugar cercano a la costa de Colima (fig. I8), procedente de Chanchopa; la calidad de la ilustración que la documenta no

53. El barro procede del río Carnero en Tepeji de Rodríguez, Puebla, a unos $250 \mathrm{~km}$ de Teotihuacan. Ahí se han localizado varios talleres especializados en la producción de formas particulares, pero aún no se sabe si las efigies se hacían ahí o en Teotihuacan: Evelyn Rattray, Teotihuacan: cerámica, cronología y tendencias culturales/Teotihuacan: Ceramics, Chronology and Cultural Trends (México: Instituto Nacional de Antropología e Historia/University of Pittsburgh, 200I), 316, 320. En la figura 196 de esta obra se ilustra nuestra figura 7.

54. En Kidder, Jennings y Shook, Excavations at Kaminaljuyu, Guatemala, 195, figs. 192195, se ilustra profusamente y detalla la pieza de Kaminaljuyú, así como otras cinco efigies similares conocidas hasta ahora.

55. Una pieza procedente de Xalitzintla está ilustrada en Kidder, Jennings y Shook, Excavations at Kaminaljuyu, Guatemala, fig. I95a, y en Enrique Juan Palacios, Arqueología de México. Culturas arcaica y tolteca (México: Imprenta Mundial, 1937), 2I, fig. I5; otra en Seler, vol. VI, pl. LIII-3 provendría de San Rodrigo Aljojuca, pero, a partir de sus trabajos en este sitio, Sigvald Linné dudó de este dato y, en general, de la presencia de materiales teotihuacanos en este lugar: Mexican Highland Culture: Archaeological research at Teotihuacan, Calpulalpan, and Chalchicomula in 1934-35 (Tuscaloosa: University of Alabama Press, 2003), 49-50.

56. La pieza se presentó en la tesis de Macías Goytia, "Tres Cerritos en el desarrollo social prehispánico de Cuitzeo”, 208. No se ha restaurado y se publicó solamente el detalle de la cara en Filini, The Presence of Teotihuacan in the Cuitzeo Basin, fig. 3.3c.

57. Filini, The Presence of Teotihuacan in the Cuitzeo Basin, 70. 


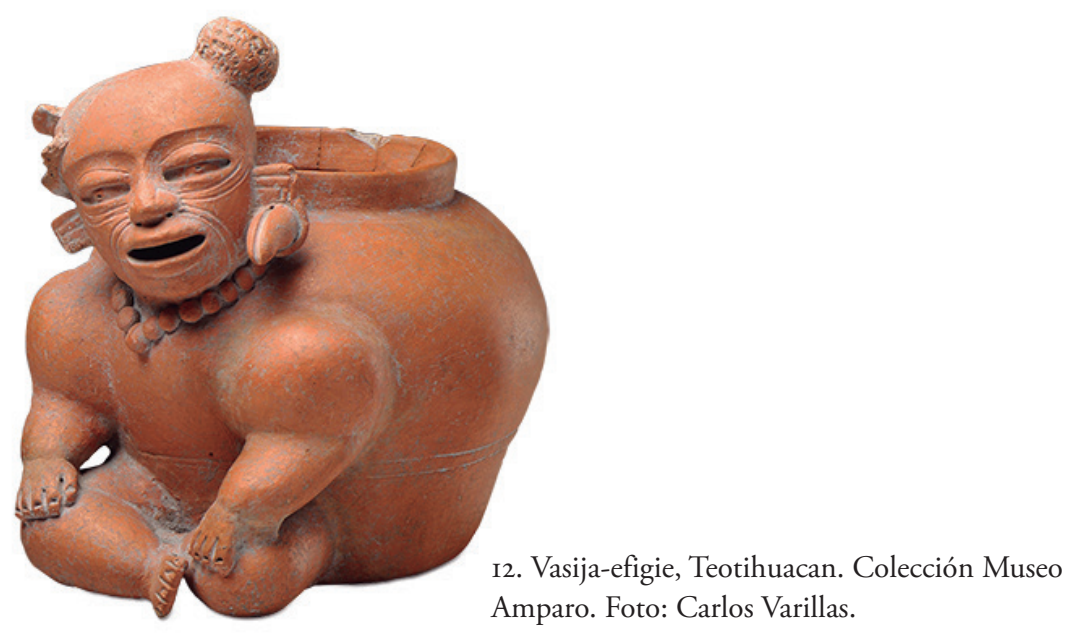

permite apreciar el tipo de vajilla al que pertenece, aunque no parece ser Anaranjado Delgado. ${ }^{58}$ La figura difiere del conjunto por la calidad inferior del modelado, por la forma simplificada del cuerpo y por el recipiente en la espalda que alude más a una canasta que a una gran olla. En esto se parece a un ejemplar procedente de Teotihuacan con el que comparte el peinado con una raya en medio y el collar inciso de tres hileras (fig. 19).59

De Chanchopa se tiene otro dato más de relación con Teotihuacan. De una tumba de tiro saqueada, Isabel Kelly rescató una vasija en Anaranjado Delgado que le permitió establecer un primer amarre cronológico para la fase Comala. ${ }^{60}$ La presencia teotihuacana en la costa se vincula con el interés de la metrópoli por adquirir las muy estimadas conchas marinas tal como se ha documentado en los trabajos ya mencionados de José Beltrán en el sitio de Playa del Tesoro.

¿Cómo interpretar la presencia de esta imagen del buceador en la perspectiva del intercambio marítimo entre el mundo mesoamericano y el andino y, en particular, su presencia en la ecúmene teotihuacana? Hasta ahora no se ha reconocido en el universo de la gran ciudad indicio concreto alguno de vínculos con el mundo andino. A primera vista se podría considerar que la efigie del

58. Artes de México: Culturas de Occidente, núm. II9, año XVI-I (I969): 63.

59. En este sentido, sólo estos dos ejemplares merecen el nombre de "canastero", comúnmente utilizado en Ecuador y Colombia para este tipo de representaciones.

6o. Con base en los estudios de Evelyn Rattray sobre el Anaranjado Delgado, Isabel Kelly ubica la pieza en una fecha posterior a 450 de la era: Kelly, Ceramic Sequence, 7. 
I3. Vasija-efigie con anteojeras, Museo Anahuacalli. Tomada de Museo Diego Rivera-Anahuacalli (México: Comité Organizador de los Juegos de la XIX Olimpiada, 1968), s. p. Secretaría de

Cultura-INAH-Méx. "Reproducción autorizada por el Instituto Nacional de Antropología e Historia”.

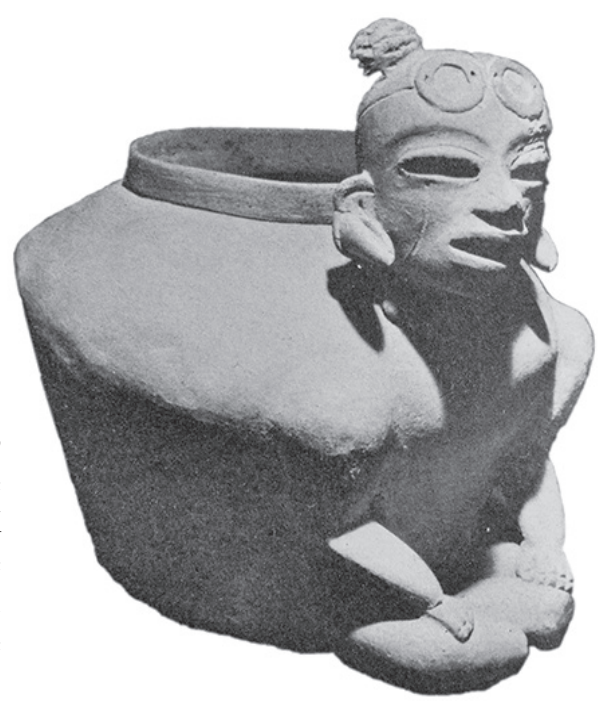

buceador ofreciendo las valiosas conchas correspondería solamente a la relevancia que pudieron haber tenido para los teotihuacanos semejantes bienes procedentes del océano, tal como se puede apreciar en otras expresiones artísticas, como son sus innumerables representaciones en los suntuosos murales de la ciudad o la imagen del hombre buceando y recogiendo conchas en una red, presente en los murales de Tetitla.

Más allá de la asombrosa similitud formal de la efigie con los llamados canasteros sureños y de la coincidencia en el alto valor simbólico y ritual acordado a estos bienes del mar, similar al que desde tiempos muy remotos habían alcanzado en el mundo andino, hay otros elementos más para proponer que efectivamente Teotihuacan, más allá de sus relaciones con los pueblos de la costa del Pacífico, estaba inmersa en las redes tendidas a escala continental por grandes navegantes y mercaderes sureños.

Los estudiosos del Occidente de México concuerdan en que el sustrato sudamericano presente desde tiempos remotos dotó a esta región de gran originalidad respecto del resto de Mesoamérica y, por tanto, al comerciar con las comunidades del Occidente los teotihuacanos muy probablemente se habrían enterado de la existencia de personajes procedentes del inmenso océano. Más allá de la simple adquisición de bienes prestigiosos, entrar en contacto con ellos significaba el acceso a una red inconmensurablemente dilatada de cono- 

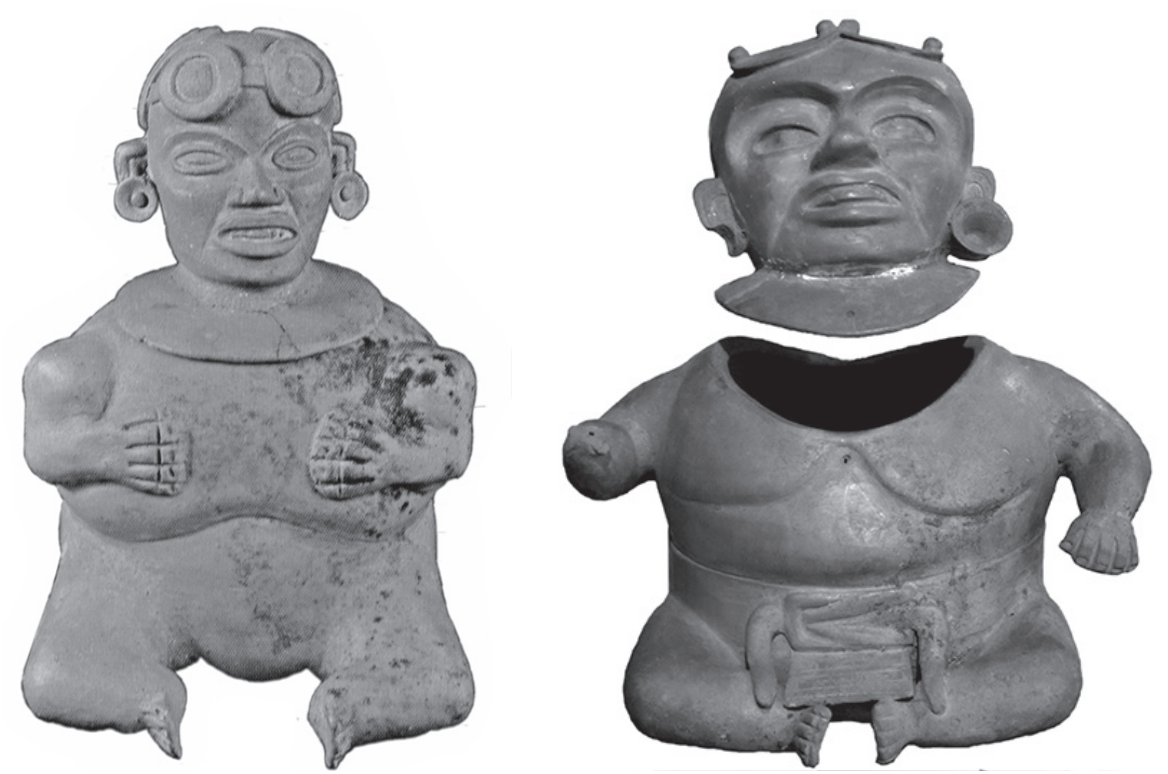

I4. Vasijas-efigie con anteojeras. La cabeza del personaje es la tapa de la olla; a) tomada de López Pérez, "Cerámica" (vid supra, n. 3I), I5I; b) Colección Stavenhagen, Centro Cultural Tlatelolco-unam. Foto: Patricia Carot. Secretaría de Cultura-INAH-Méx. "Reproducción autorizada por el Instituto Nacional de Antropología e Historia”;

cimientos. Por lo que una metrópoli cuyo prestigio se debía en gran medida a su fuerza de atracción como centro de peregrinación y de intercambios habría tenido interés en formar parte de esta red en la cual el Spondylus había alcanzado desde tiempos inmemoriales un valor que excedía el simple campo de la ritualidad, y se había convertido, a modo de moneda, en el parámetro del comercio a larga distancia. La recreación de la efigie del buceador representada por los artistas teotihuacanos correspondería así a las normas formales reconocidas por los grupos implicados en estos movimientos.

Entre las efigies ejecutadas en la vajilla de Anaranjado Delgado figura otro tema que sugiere no sólo contactos con el Occidente sino con el mundo andino. Se trata de la representación del perro enroscado sobre sí mismo, que puede ser reconocido como el xoloitzcuintli, el perro pelón, por las arrugas que marcan su cara, similares a las de varias de las efigies del hombre buzo (fig. 6). En su estudio detallado de las esculturas de barro de perros pertenecientes al 
I5. Huso chimu de plata que representa a un buzo sujetando

un Spondylus. Tomado de Alana Cordy-Collins, Anne Marie Hocquenghem y Maria Rostworowski, Spondylus: ofrenda sagrada y simbolo de paz (Lima: Museo Arqueológico Rafael Larco Herrrera/ Fundación Telefónica del Perú, 1999), I49.

arte de la fase Comala de Colima, Carolyn Baus de Czitrom establece varios tipos y considera que el del perro enroscado habría sido creado en Teotihuacan y que fue retomado en Colima. Su argumentación se basa ante todo en la distribución de esta figura a lo largo de la amplia ecúmene teotihuacana, en diversas partes del estado de Puebla, en Monte Albán y en Kaminaljuyú. ${ }^{6 r}$ Como se señaló anteriormente, el perro lampiño es una de las evidencias más elocuentes de los contactos marítimos con el mundo andino, como acompañante de los audaces navegantes y mercaderes en sus largas travesías. Por tanto, no es una simple coincidencia que entre las efigies teotihuacanas figuraran el perro lampiño y el buceador, ambas aludían a un mundo de dimensiones inconmensurables abierto por gente de mar, apertura hasta ahora inadvertida en relación con Teotihuacan. Para tejer estas relaciones, la gran metrópoli contaba con un intermediario privilegiado: la gente de Michoacán directamente ligada a la vida de la metrópoli y al mismo tiempo en contacto constante mediante sus redes comerciales con las comunidades de la costa.

Con el colapso de Teotihuacan, a finales del siglo vi, desapareció de Mesoamérica esta figura que evocaba a la vez al proveedor del alimento de los dio-

6I. Baus de Czitrom, Los perros de la antigua provincia de Colima, 26. 


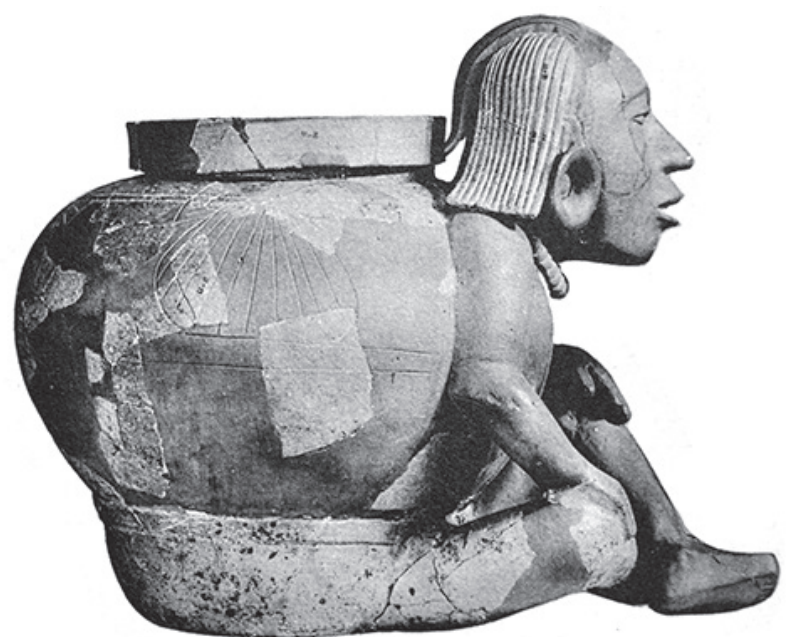

I6. Vasija-efigie con figuras incisas de conchas sobre la olla, Kaminaljuyú, Guatemala. Tomada de Kidder, Jennings y Shook, Excavations at Kaminaljuyu, Guatemala (vid supra, n. 52), fig. 192.

ses y los intercambios con mercaderes originarios de lejanas regiones sureñas. Se desconoce la historia azarosa de estos vínculos marítimos a lo largo de los siglos siguientes, hasta que se reanudaron con fuerza renovada hacia el siglo IX o X, tal como lo atestiguan los datos mencionados de Placeres del Oro. Pero esta vez con acceso a conocimientos y experiencias sureños largo tiempo vetados a los mesoamericanos: los secretos de la metalurgia.

\section{Los tarascos y el regreso a los orígenes}

Por último, terminaremos con otro objeto que atestigua la importancia que los michoacanos atribuían a sus relaciones con estos lejanos pueblos sureños: la famosa vasija de asa de estribo.

Como mencionamos en un principio, esta forma singular apareció desde el inicio de la civilización andina en el tercer milenio antes de la era actual. En la ceja amazónica, en el sitio de La Florida-Chinchipe, se presenta bajo formas diversas, naturalistas y geométricas, en el ajuar de personajes importantes asociados a prácticas chamánicas, junto con un recipiente que ofrece la representación más antigua de coquero. Esas vasijas aparentemente servían para bebidas como el cacao y la chicha, ingeridas en rituales, y se reservaban para personajes destacados, que se beneficiaban de redes muy extensas de 

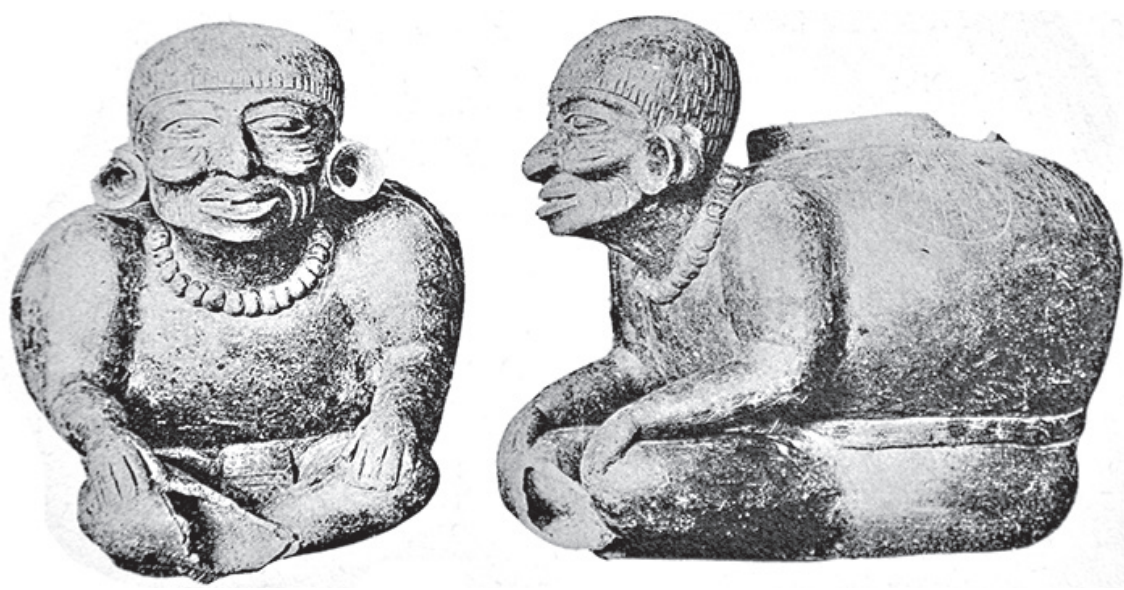

17. Vasija-efigie con cuerpo de joven y cara de anciano, olla decorada con figuras incisas de conchas, Toluca. Tomada de Kidder, Jennings y Shook, Excavations at Kaminaljuyu, Guatemala (vid supra, n. 52), fig. I94b.

intercambio transandino, centrado en bienes con alto valor simbólico como las valiosas conchas de Strombus y Spondylus de las aguas calientes de la costa ecuatoriana. Precisamente, una de esas vasijas de asa de estribo representa dos caras humanas que emergen de una concha de Spondylus. ${ }^{62}$ Así, desde los inicios, esa forma peculiar de recipiente integró un conjunto de objetos indispensables para la vida ritual.

Después, con variaciones formales menores, en las culturas Valdivia, Machalilla, Chorrera y Cotocoallao el asa de estribo perduró en la costa, sierra y selva ecuatorianas hasta finales del Formativo Medio, mientras que en el Perú se introdujo en el Horizonte Temprano y nunca se abandonó hasta tiempos de la conquista española. ${ }^{63}$

En Mesoamérica, la vasija de asa de estribo figuró en el primer conjunto de elementos ligados a la religión y al ritual que, hace más de tres milenios, se introdujeron en el Occidente desde el Ecuador, en la fase Capacha de Colima

62. Valdez, "Mayo Chinchipe: la puerta entreabierta", en Ecuador. El arte secreto del Ecuador precolombino, eds. Daniel Klein e Iván Cruz Cevallos (Milán: Casa del Alabado/s Continentes Ediciones, 2007), 336-338.

63. Valdez, "Mayo Chinchipe, el otro Formativo Temprano", I8I-I83. 


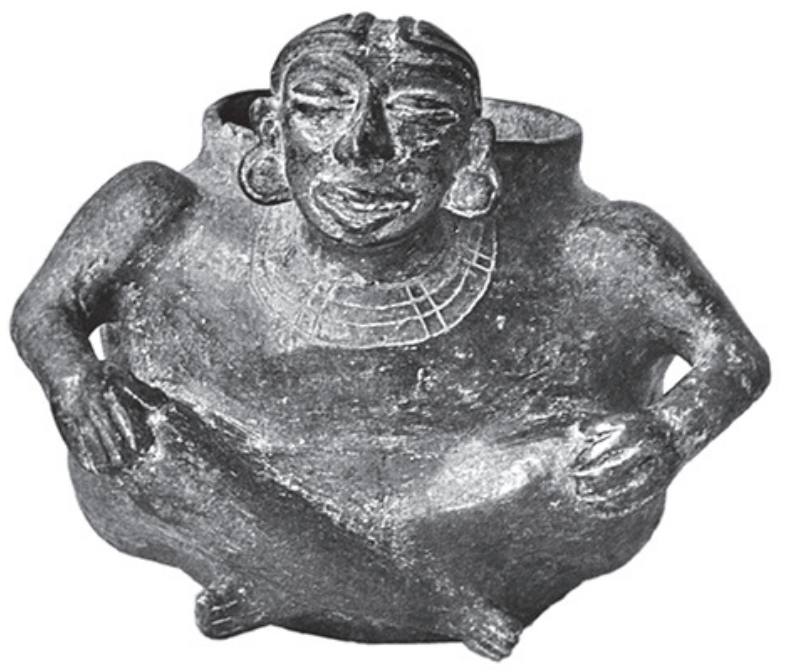

I8. Vasija-efigie procedente de Chanchopa, Colima. Tomada de Artes de México: Culturas de Occidente (vid supra, n. 58), 63. Secretaría de Cultura-INAH-Méx. "Reproducción autorizada por el Instituto Nacional de Antropología e Historia”.

y luego en la cultura de Tlatilco del Valle de México y Morelos. ${ }^{64}$ Este influjo sudamericano introducido vía el Occidente, constituye el llamado tertium quid de la fase Manantial (I0oo-80o a.C.) que, junto con la herencia olmeca y la tradición local, configuró esta etapa tan importante del devenir mesoamericano. Después la vasija de asa de estribo se abandonó salvo en el arte Chupícuaro de los últimos siglos antes de la era actual. ${ }^{65}$ Luego desapareció durante más de un milenio hasta que los tarascos de las últimas décadas antes de la llegada de los españoles retomaron esta forma (fig. 20).

¿Pura coincidencia? Lo dudamos porque como lo hemos documentado ampliamente, ${ }^{66}$ los tarascos mantuvieron un interés sostenido por recupe-

64. Carolyn Baus de Czitrom y Patricia Ochoa Castillo, "El estilo Tlatilco y su relación con el complejo cerámico Capacha”, en El Preclásico o Formativo. Avances y perspectivas. Seminario de arqueología "Dr. Román Piña Chan", coord. Martha Carmona Macías (México: Instituto Nacional de Antropología e Historia-Museo Nacional de Antropología, 1989), 32I.

65. Se conocen dos vasijas con asa de estribo. Una publicada en Jay D. Frierman, The Natalie Wood Collection of Pre-Columbian Ceramics from Chupicuaro, Guanajuato, Mexico, ed. Jay D. Frierman (Los Ángeles: University of California/Museum and Laboratories of Ethnic Arts and Technology, 1969), I3-I4 y 52, pieza n. II9; la otra se encuentra en el Museo Michoacano de Morelia: Porter, Excavations at Chupicuaro: fig. I2-s; Porter, The Aztecs, Maya, and Their Predecessors, 96.

66. Patricia Carot, "Apropiarse del arte de los orígenes: estrategia del imperio tarasco", en XXXII Coloquio Internacional de Historia del Arte. Apropiarse del arte; impulsos y pasiones, ed. 
19. Vasija-efigie, Teotihuacan. Tomada de López Pérez, "Cerámica" (vid. supra, n. 3I), I5I. Secretaría de Cultura-INAHMéx. "Reproducción autorizada por el Instituto Nacional de Antropología e Historia”.

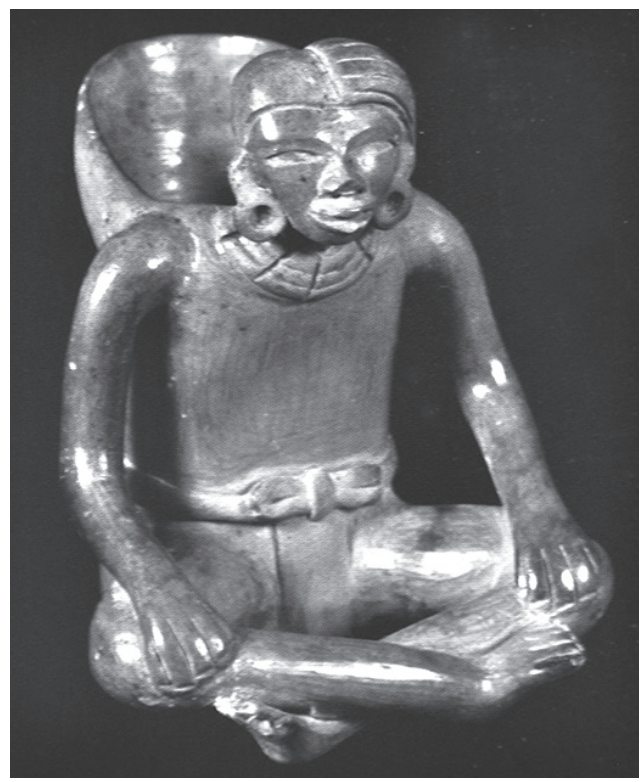

rar formas, imágenes y objetos del pasado y afirmar así sus profundas raíces ancladas en estas tierras, de manera similar a lo que hicieron los mexicas en la misma época, en las ofrendas del Templo Mayor. Los mexicas quisieron subrayar sus raíces teotihuacanas y toltecas. Los tarascos enfatizaron su pasado en lo que ahora se denomina fase Loma Alta, una etapa en la cual estuvieron ligados al destino de la gran Teotihuacan, pero que dio también lugar a la migración de algunos hacia lejanas tierras norteñas. De igual manera tuvieron interés en conservar el contacto desde tiempos inmemoriales con los pueblos remotos, que por medio de viajes marítimos les compartieron los secretos de la metalurgia y de un mundo aparentemente sin límites. Para el caso de la vasija con asa de estribo, no se sabe si los alfareros tarascos copiaron la forma de ejemplares antiguos del periodo Chupícuaro, que habrían recuperado tal como sucedió con las reproducciones de obras antiguas de la fase Loma Alta, o si se inspiraron en las vasijas que utilizaban los fuereños del sur con quienes seguían en contacto.

Olga Sáenz (México: Universidad Nacional Autónoma de México-Instituto de Investigaciones Estéticas, 2012), 7I-92. 


\section{Conclusión}

Con nuestra digresión sobre la larga historia purépecha, esperamos haber despejado el aparente callejón sin salida en el que se había quedado atorada la propuesta de Anawalt en cuanto a la participación relevante de los tarascos en los intercambios marítimos con el mundo andino. Al retomar los avances significativos alcanzados en la arqueología tanto de Michoacán como del septentrión mesoamericano, sostenemos que los tarascos no eran ni nómadas ni recién llegados, sino que tuvieron una muy larga historia en tierras michoacanas, y participaron plenamente de la ecúmene teotihuacana; más adelante, la migración de un grupo hacia el lejano norte chalchihuiteño los llevó a establecer lazos significativos con antiguas comunidades hohokam del desierto de Arizona. Esta faceta de su historia permite reconocerlos como un pueblo proclive a abrir nuevos horizontes por medio de migraciones y de redes comerciales a distancias considerables. Señalamos, asimismo, que en esta gesta norteña les fue de gran apoyo el saber astronómico, heredado de su pertenencia al universo teotihuacano, útil para explorar nuevas rutas por tierra, pero también para la navegación.

Esos incidentes norteños permiten entender mejor la insólita presencia en Guerrero de las famosas paletas de piedra típicas de la cultura hohokam y abordar con mayor información la conjunción aún más sorprendente del famoso sepulcro de Placeres del Oro: una paleta hohokam y relieves con estilo de origen andino tal como lo había indicado hace tiempo el artista Covarrubias. Avances recientes en la arqueología de esta región de Guerrero reabren este enigma, planteado hace ya más de un siglo, con mayores elementos que apuntan hacia relaciones tanto con el lejano norte como con tierras más allá de los mares del sur. Por lo que habrá que proseguir con la búsqueda de nuevos elementos para saber en qué medida los tarascos o purépechas estuvieron implicados en estos contactos, entrando así en el ámbito de las relaciones marítimas, poco tratadas en la arqueología mesoamericana, pero ya ampliamente aceptadas en la ecuatoriana.

Sin posibilidad de documentar navegaciones antiguas, abordamos temas estrechamente relacionados: el Spondylus como bien suntuario, de alto valor simbólico, pero también como medio por excelencia para rescatar mercancías; asociado a ello, el buceador, el héroe de las profundidades, proveedor de los mercaderes y de los dioses, y, el singular perro pelón que, como acompañante de los navegadores, alcanzó una dispersión continental. La presencia en diversos momentos del singular botellón de asa de estribo confirmó que estos 


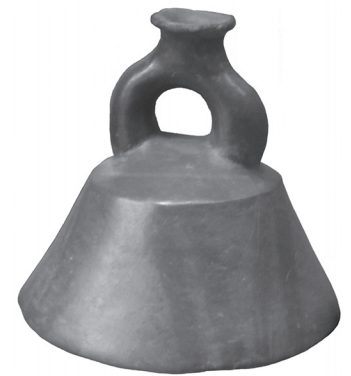

a

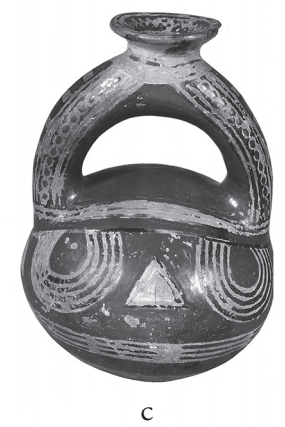

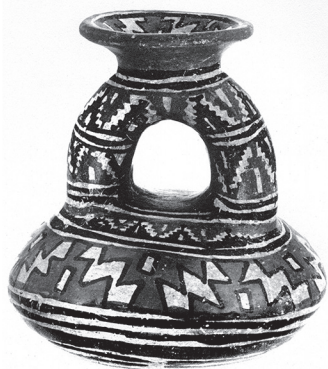

b

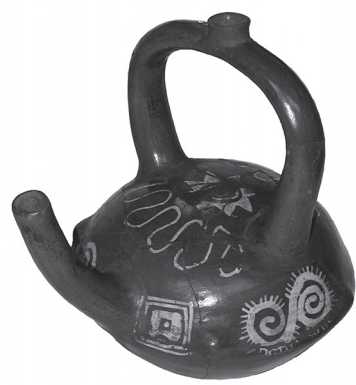

$\mathrm{d}$

20. Vasijas con asa de estribo: a) Tlatilco, Museo Nacional de Antropología. Foto: MarieAreti Hers; b) tradición Chupícuaro, Colección Natalie Wood. Tomada de The Natalie Wood Collection (vid supra n. 65), pieza núm. II9; c) tradición Chupícuaro, Museo Regional Michoacano. Tomada de Eduard Williams, "Los tarascos y sus antepasados; una perspectiva antropológica”, en El Michoacán antiguo, coord. Brigitte Boehm de Lameiras (Zamora: El Colegio de Michoacán/Gobierno del Estado de Michoacán, 1994), I68; d) Posclásico tarasco. Bodega del Museo Nacional de Antropología. Foto: Marie-Areti Hers. Secretaría de CulturaINAH-Méx. "Reproducción autorizada por el Instituto Nacional de Antropología e Historia".

intercambios fueron indisociables de ciertos rituales en los cuales se tomaban bebidas poderosas, en particular en funerales de personajes de alto rango.

Para rastrear información acerca de los buceadores, aprovechamos un elemento presente en trabajos de antropología física, pero aún insuficientemente aquilatado: la exóstosis auditiva como testimonio concreto de los buzos profesionales y sus hondas zambullidas para conseguir las conchas tan preciadas. En los casos reportados, las evidencias apuntan hacia las relaciones directas de estos buzos con el Occidente, tanto en el caso de los hallazgos en la Tula del 
Epiclásico como en tierras michoacanas. Encontramos también la huella de los buceadores al retomar una propuesta bien establecida para el mundo ecuatoriano y colombiano, pero sin eco hasta ahora en México: el de las figuras de "canasteros" como emblema de un gremio de mercaderes que habría dominado los contactos marítimos continentales a lo largo de siglos. Al examinar esas figuras de cerca, constatamos que se trata de una imagen recreada en Teotihuacan bajo la forma del buzo, asociando directamente esas redes de intercambio con la adquisición del Spondylus. De esa manera, se hace patente un aspecto insospechado hasta ahora para la historia teotihuacana: el interés de la metrópoli por estas redes de intercambio marítimo, en las cuales los michoacanos habrían sido los intermediarios privilegiados entre la gran urbe, la gente de la costa y los navegantes de lejano origen.

Indisociable a esta historia de buzos y navegantes, indagamos la del perro pelón. Revisamos datos dispersos y a veces contradictorios para asentar que su difusión continental se debe en efecto a la acción humana y más precisamente a la de los viajeros mercaderes, pero subrayando los puntos que aún faltan por documentar de manera satisfactoria antes de saber dónde se originó y cuándo se difundió este testigo tan elocuente de los grandes viajes marítimos.

En cada punto abordado, los michoacanos aparecieron como los intermediarios por excelencia, como comunidades muy dadas al intercambio sobre larguísimas distancias, a reconocer nuevas tierras, al migrar y explorar como fenicios mesoamericanos. La famosa vasija de asa de estribo permitió además saberlos conscientes de su historia de migraciones, exploraciones y navegaciones por mar y tierra. \$s

N.B. Agradecemos el apoyo recibido por parte del proyecto Papiit-IN4OI8II, Tláloc y las entidades de la lluvia en la América indígena, del Instituto Nacional de Patrimonio Cultural del Ecuador y de la organización cultural Pueblos de América. Una versión preliminar del presente trabajo fue presentada en el Segundo Coloquio Internacional de Arte: Arquitectura, Cosmovisión y Patrimonio Cultural en el Mundo Mesoamericano y Andino, Quito, mayo de 2012. 